Article

\title{
Evolution of Pyrite Compositions at the Sizhuang Gold Deposit, Jiaodong Peninsula, Eastern China: Implications for the Genesis of Jiaodong-Type Orogenic Gold Mineralization
}

\author{
Zhankun Liu ${ }^{1,2} \mathbb{0}$, Xiancheng Mao ${ }^{1, *(1)}$, Andrew Jedemann ${ }^{2}$, Richard C. Bayless ${ }^{1}$, Hao Deng ${ }^{1}$, Jin Chen ${ }^{1}$ \\ and Keyan Xiao ${ }^{3}$ \\ 1 Key Laboratory of Metallogenic Prediction of Nonferrous Metals and Geological Environment \\ Monitoring (Ministry of Education), School of Geosciences and Info-Physics, Central South University, \\ Changsha 410083, China; zkliu0322@csu.edu.cn (Z.L.); richardbayless@protonmail.com (R.C.B.); \\ haodeng@csu.edu.cn (H.D.); chenjin215@hotmail.com (J.C.) \\ 2 Department of Geology, Lakehead University, 955 Oliver Road, Thunder Bay, ON P7B 5E1, Canada; \\ atjedema@lakeheadu.ca \\ 3 MLR Key Laboratory of Metallogeny and Mineral Resource Assessment, Institute of Mineral Resources, \\ Chinese Academy of Geological Sciences, Beijing 100037, China; kyanxiao@sohu.com \\ * Correspondence: mxc@csu.edu.cn; Tel.: +86-731-888-77571
}

Citation: Liu, Z.; Mao, X.; Jedemann, A.; Bayless, R.C.; Deng, H.; Chen, J.; Xiao, K. Evolution of Pyrite Compositions at the Sizhuang Gold Deposit, Jiaodong Peninsula, Eastern China: Implications for the Genesis of Jiaodong-Type Orogenic Gold Mineralization. Minerals 2021, 11, 344

https://doi.org/10.3390/min11040344

Academic Editors: Tamer Abu-Alam and Basem Zoheir

Received: 14 February 2021

Accepted: 23 March 2021

Published: 26 March 2021

Publisher's Note: MDPI stays neutra with regard to jurisdictional claims in published maps and institutional affiliations.

Copyright: (c) 2021 by the authors. Licensee MDPI, Basel, Switzerland. This article is an open access article distributed under the terms and conditions of the Creative Commons Attribution (CC BY) license (https:// creativecommons.org/licenses/by/ $4.0 /)$.
Abstract: Gold deposits in the Jiaodong Peninsula represent a primary gold resource in China and mostly exhibit similar ore-forming features related to sericite-quartz-pyrite alteration and other controls from (micro-)structural deformation. This study investigates the pyrite textures and trace elements in the Sizhuang gold deposit $(>100 \mathrm{t} \mathrm{Au})$ to document the key factors impacting on the genesis of the Jiaodong-type orogenic deposits. Three main types of pyrite are identified: (1) the first generation of pyrite (Py1) occurs as disseminated euhedral to subhedral grains in K-feldspar-albiterutile-hematite and sericite alteration (stage 1), (2) Py2 as aggregates in quartz-sericite-pyrite altered rocks or quartz-pyrite veins (stage 2) can be subdivided into Py2a as irregular cores, Py2b as a zoned overgrowth on Py2a, and Py2c as overgrowth on early pyrite, and (3) Py3 as fine-grained crystals in siderite-polymetallic veins (stage 3). Primary gold at the Sizhuang deposit is coevally or slightly later deposited with Py2b, Py2c, and Py3. Laser ablation-inductively coupled plasma mass spectrometry (LA-ICP-MS) analyses show that the highest Co and Ni contents in Py1 and high but variable Co in Py $2 b$ favors the involvement of deep high-temperature magmatic waters at stage 1 and middle stage 2. The elevated As contents from Py2a to Py2c and depletion of trace elements (e.g., Co, Ni, As and $\mathrm{Te}$ ) and high $\mathrm{Au} / \mathrm{Co}, \mathrm{Cu} / \mathrm{Ni}$, and $\mathrm{As} / \mathrm{Ni}$ values in Py2a and Py3, combined with published $\mathrm{H}-\mathrm{O}$ isotope data, imply a meteoric water ingress during stage $2-3$. Thus, the fluid evolution at Sizhuang is a consequence of pulsed deep magmatic fluid release plus progressive meteoric fluid ingress. The rhythmic $\mathrm{Co}-\mathrm{As}-\mathrm{Ni}-\mathrm{Au}$ bands of Py2b additionally suggest episodic changes in the composition of ore-forming fluids. Moreover, the sharp textural features (e.g., pyrite overgrowth on previously cataclastic crystals) of Py2 and As-Cu-rich and Co-poor bands in zoned Py2b probably also reflect rapid metal deposition and self-organization and subsequent mineral crystal growth due to the pressure release during phase separation in the Sizhuang deposit. Considering the significantly concentrated gold (>1300 t) in the regional Jiaojia fault zone and Au-bearing mineral formation related to phase separation (boiling) in the Sizhuang deposit, gold mineralization in the Sizhuang deposit was interpreted to be controlled by the pressure-driver owing to the seismic activities in the Jiaojia fault system.

Keywords: pyrite geochemistry; fluid evolution; fault-valve model; Sizhuang deposit; Jiaodong-type orogenic gold deposit 


\section{Introduction}

The Jiaodong Peninsula located in the eastern portion of the North China Craton (Figure 1) represents the largest gold province in China with a measured resource of $>5000 \mathrm{t} \mathrm{Au} \mathrm{[1-5].} \mathrm{Gold} \mathrm{deposits} \mathrm{in} \mathrm{the} \mathrm{Jiaodong} \mathrm{Peninsula} \mathrm{(Jiaodong-type} \mathrm{deposits)} \mathrm{are}$ fundamentally similar to typical orogenic gold deposits in the greenstone belt, such as low-salinity, $\mathrm{CO}_{2}$-rich, and mid- to high-temperature fluid conditions [6-9]. However, the gold mineralization, dated at about $120 \pm 5 \mathrm{Ma}$, significantly post-dates the age of the host rocks, which include the Precambrian metamorphic rocks, 160-155 Ma Linglong or Kunyushan granite, and 130-125 Ma Guojialing granite [10-12]. This is in contrast to the syn-metamorphic origin for orogenic gold deposits in Archean greenstone belts [3,13-15]. For this reason, the term "Jiaodong-type orogenic deposit" has been proposed to distinguish these unique Cretaceous gold deposits in the Jiaodong Peninsula $[1,7,16,17]$.

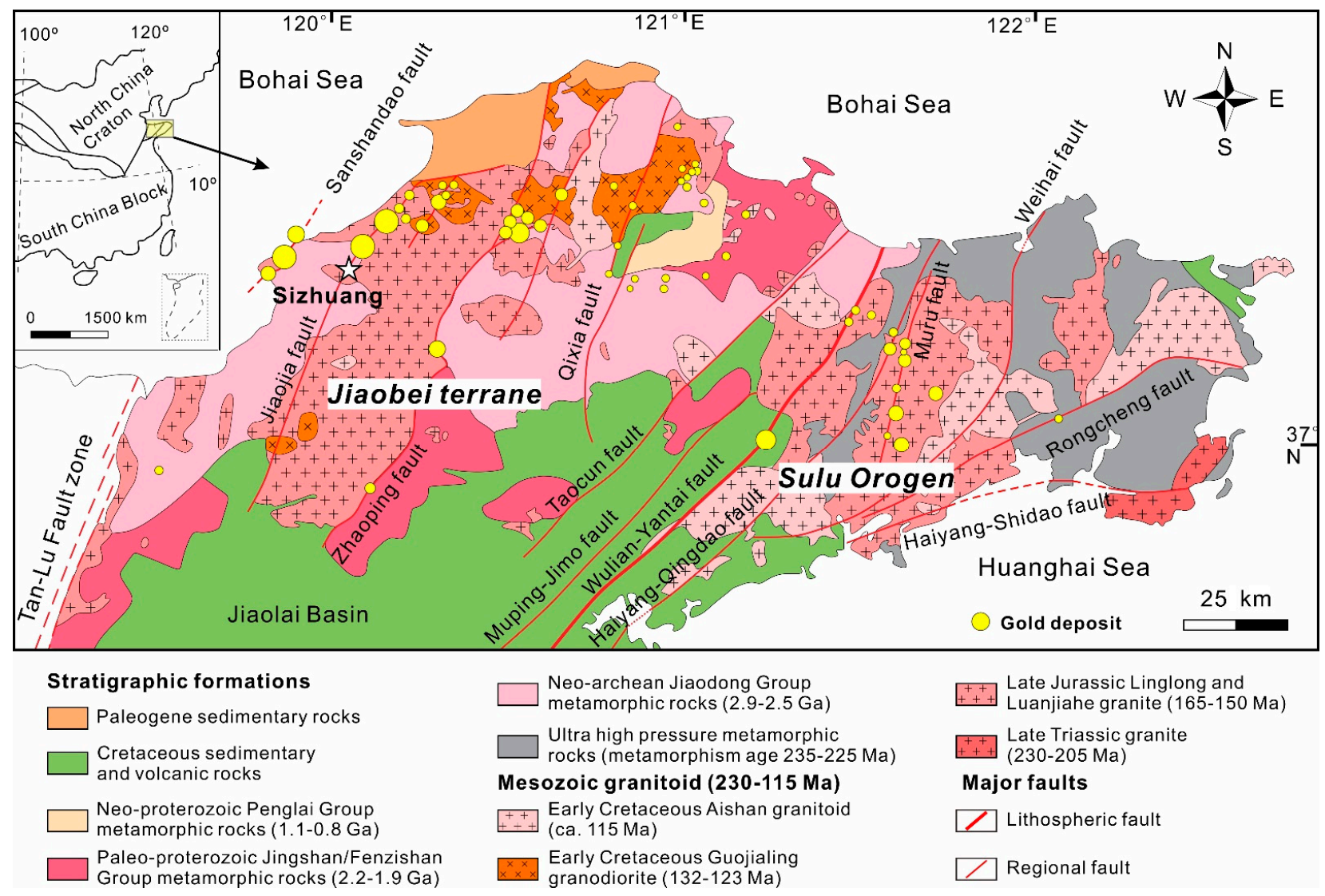

Figure 1. Simplified map showing the tectonic units, structures, lithologies, and major gold deposits in the Jiaodong Peninsula and the location of the Sizhuang gold deposit. (Modified from [18]).

Gold mineralization of many Jiaodong-type orogenic deposits has a number of features in common, including (1) they typically have an early K-feldspar stage, intermediate quartz-sericite-pyrite and quartz-(siderite)-polymetallic stages as the primary ore-forming periods, and a post-ore quartz-calcite stage [7,10,17,19-21], and (2) gold emplacement with preferential localization in the hanging or footwall of detachment faults $[3,5,22,23]$. These common characteristics imply that coupling of fluid evolution and structural deformation likely played a critical role in generating the Jiaodong-type gold deposits.

Pyrite is an ubiquitous mineral associated with gold in several types of hydrothermal gold deposits [24-31]. Numerous studies have demonstrated that pyrite can effectively incorporate a wide range of metal and metalloids (e.g., $\mathrm{Au}, \mathrm{Ag}$, $\mathrm{As}, \mathrm{Cu}, \mathrm{Co}, \mathrm{Ni}, \mathrm{Te}, \mathrm{Pb}$, and $\mathrm{Bi})$, depending on the fluid compositions, geochemical properties of dissolved elements, and the precipitation processes $[29,31-36]$. Furthermore, the diversity of textural features 
in pyrite (e.g., cataclastic, zonation, replacement, and recrystallization) in hydrothermal gold systems is interpreted as a result of complex growth processes during ore-forming evolution $[24,31,36-41]$. Hence, synthetic studies on pyrite geochemistry and texture at the micron- and/or atomic-scale by advanced analytical techniques, such as scanning electron microscopy, electron probe micro-analyzer (EPMA), laser ablation-inductively coupled plasma mass spectrometry (LA-ICP-MS), secondary ion mass spectrometry, and atom probe tomography, have been popularly applied to probe (1) metals and metalloids incorporation forms [33,34,42-46], (2) pyrite crystallization history and metals and metalloids precipitation, partition, remobilization, and redistribution [36,38,40,41,47], (3) fluid sources, conditions, and evolution [27-30,33,48], and (4) metallogenesis of mineral systems $[28,29,32,35,39,43,47-49]$.

Pyrite is commonly precipitated during several ore-stages of the Jiaodong-type gold deposits and gold occurs as free milling inclusions within pyrite or fillings into pyrite cracks, implying a simultaneous or slightly lag precipitation of gold and pyrite $[18,25,50,51]$. Moreover, pyrite often exhibits the cataclastic, zoned, and/or overgrowth textures associated with multiple micro-structural deformation events that, at least partly, control gold deposition from fluids in the Jiaodong gold deposits [18,51,52], providing an excellent record of the fluid kinetic environment during mineralization. The Sizhuang gold deposit with a proven reserve of more than $100 \mathrm{t}$ gold is located along the Jiaojia fault, northwest Jiaodong Peninsula [53]. Here we present a detailed investigation of pyrite textures and trace element chemistry of the Sizhuang pyrite to understand gold precipitation and fluid evolution of the Sizhuang deposit as well as the ore genesis of the Jiaodong-type orogenic deposits.

\section{Geological Background}

The Jiaodong Peninsula consists of two major blocks: the Jiaobei terrane and Sulu orogenic belt. They are separated by the Wulian-Yantai fault (Figure 1). Most of the orogenic gold deposits in the Jiaodong Peninsula are hosted in NNE- or NE-striking detachment faults, such as the Sanshandao, Jiaojia, and Zhaoping faults, in the west Jiaobei terrane (Figure 1). These detachment faults developed as a result of three-stages of deformation: (1) compressional to transpressional deformation under NW-SE principal stress related to paleo-Pacific subduction in the pre-ore stage (>130 Ma), (2) transtensional to extensional deformation under NW-SE minimum principal stress during slab rollback in the syn-ore stage (120 $\pm 5 \mathrm{Ma})$, and (3) compressional to transpressional deformation under WNW minimum principal stress in the post-ore stage [22,54]. The NNE- to NE-trending Jiaojia fault extends over more than $60 \mathrm{~km}$ and is associated with more than 20 gold deposits (e.g., Sizhuang, Matang, Jiaojia, and Xincheng) with a total gold resource of $1300 \mathrm{t}[18,53]$.

The Sizhuang gold deposit is located in the southern part of the Jiaojia ore-field (Figure 1). Major lithological units exposed around Sizhuang are the Malianzhuang amphibolite (meta-gabbro) of the Archean Jiaodong Group and the Late Jurassic Linglong biotite monzonitic granite (Figures $2 \mathrm{a}$ and $3 \mathrm{a}$ ). The Linglong granite hosts the most ore at Sizhuang and consists of plagioclase ( 40 vol\%), K-feldspar ( $23 \mathrm{vol} \%)$, quartz ( $28 \mathrm{vol} \%)$, and biotite $(\sim 5 \mathrm{vol} \%)$ with minor pyroxene, zircon, titanite, and apatite [55]. 

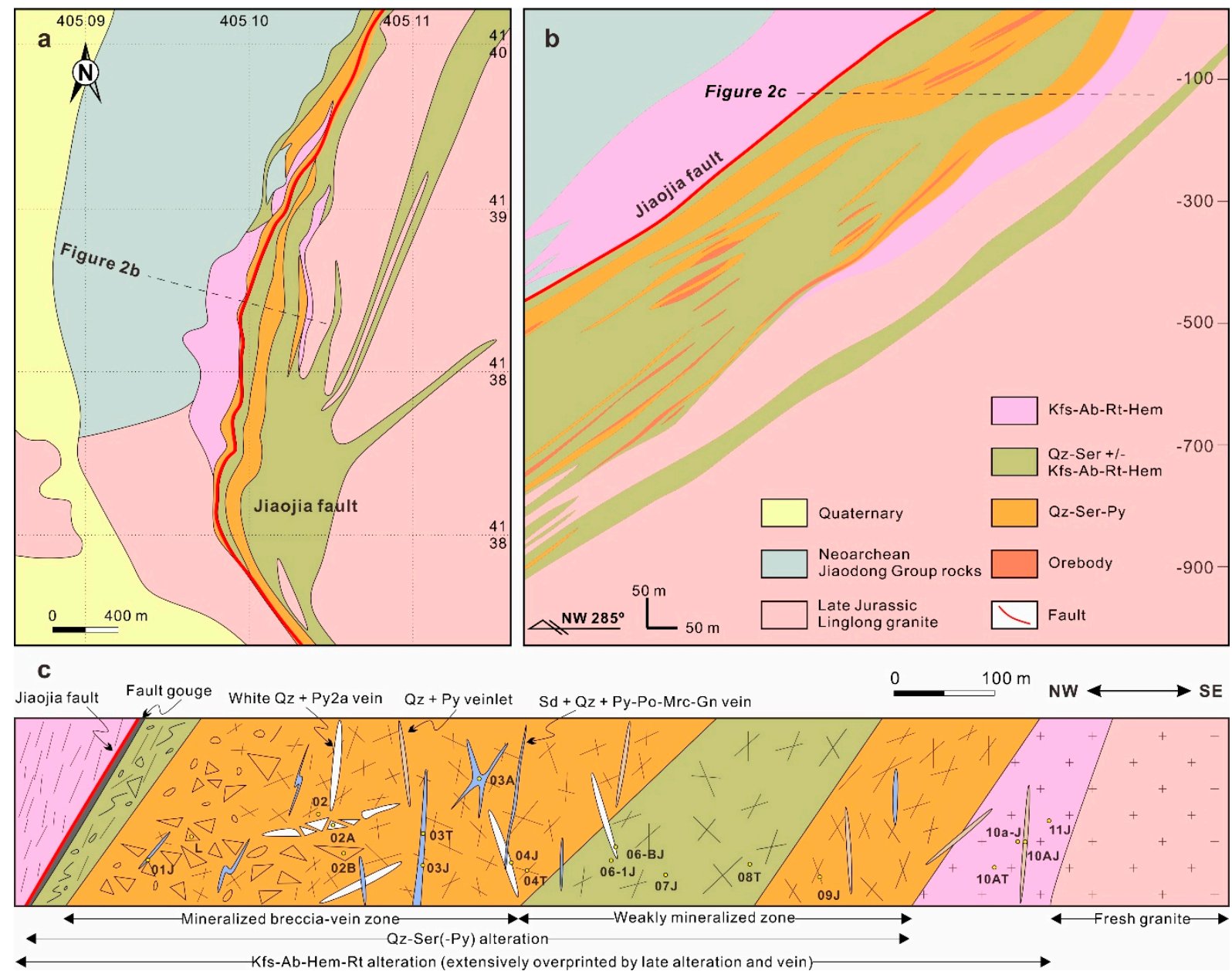

Figure 2. (a,b) Geological map and representative cross-section (line 288) of the Sizhuang gold deposit (Modified from unpublished report of No. 6 Exploration institute of geology and mineral resources of Shandong Province). (c) Mineralization and alteration section involved in this study showing sample locations and relationships among fault, breccia, vein, and alteration. The number-letters in 2c stand for sample numbers. Ab: albite; Gn: galena; Hem: hematite; Kfs: K-feldspar; Mrc: marcasite; Po: pyrrhotite; Py: pyrite; Qz: quartz; Rt: rutile; Sd: siderite; Ser: sericite.

Gold mineralization is structurally controlled by the NNE-striking and NW-dipping Jiaojia fault and secondary faults or joints in the Linglong granitoid (Figure 2). The Jiaojia fault displays hybrid ductile-brittle features with dip angles ranging from $30-45^{\circ}$ [55]. The main orebodies can be divided into three groups: (1) the No. 1 orebodies comprise disseminated ore hosted in quartz-sericite-pyrite alteration zone near to the Jiaojia fault, (2) No. 2 orebodies are found in quartz/siderite-sulfide veins and veinlets in sericite-quartz altered rocks, and (3) No. 3 orebodies form distal mineralization consisting of quartzsulfide veins in K-feldspar-albite-rutile alteration [53,56]. The No. 1 orebodies account for more than $40 \%$ of total gold resource of the Sizhuang deposit and are found at depths of less than $900 \mathrm{~m}$. They vary in thickness from 1 to $24 \mathrm{~m}$, extend 200 to $1200 \mathrm{~m}$ down plunge with a strike of $2-30^{\circ}$ and a NW dip of $21-41^{\circ}$ [56]. The gold grade varies from 1.2 to $5.5 \mathrm{~g} / \mathrm{t}$. The No. 2 orebodies account for only $1.4 \%$ of the known gold resource [56], and mainly consists of 20 small-scale orebodies at the -159 to $-920 \mathrm{~m}$ levels. The No. 3 orebodies include more than 130 orebodies and contains about $58 \%$ of the gold at Sizhuang. The orebodies generally occur as veins, stratiform-like, or lenses, striking $342-028^{\circ}$, dipping $23-47^{\circ} \mathrm{NW}$, extending $905 \mathrm{~m}$ along strike, with a thickness of $0.8-16.1 \mathrm{~m}$ and gold grade of $1-26 \mathrm{~g} / \mathrm{t}$. 

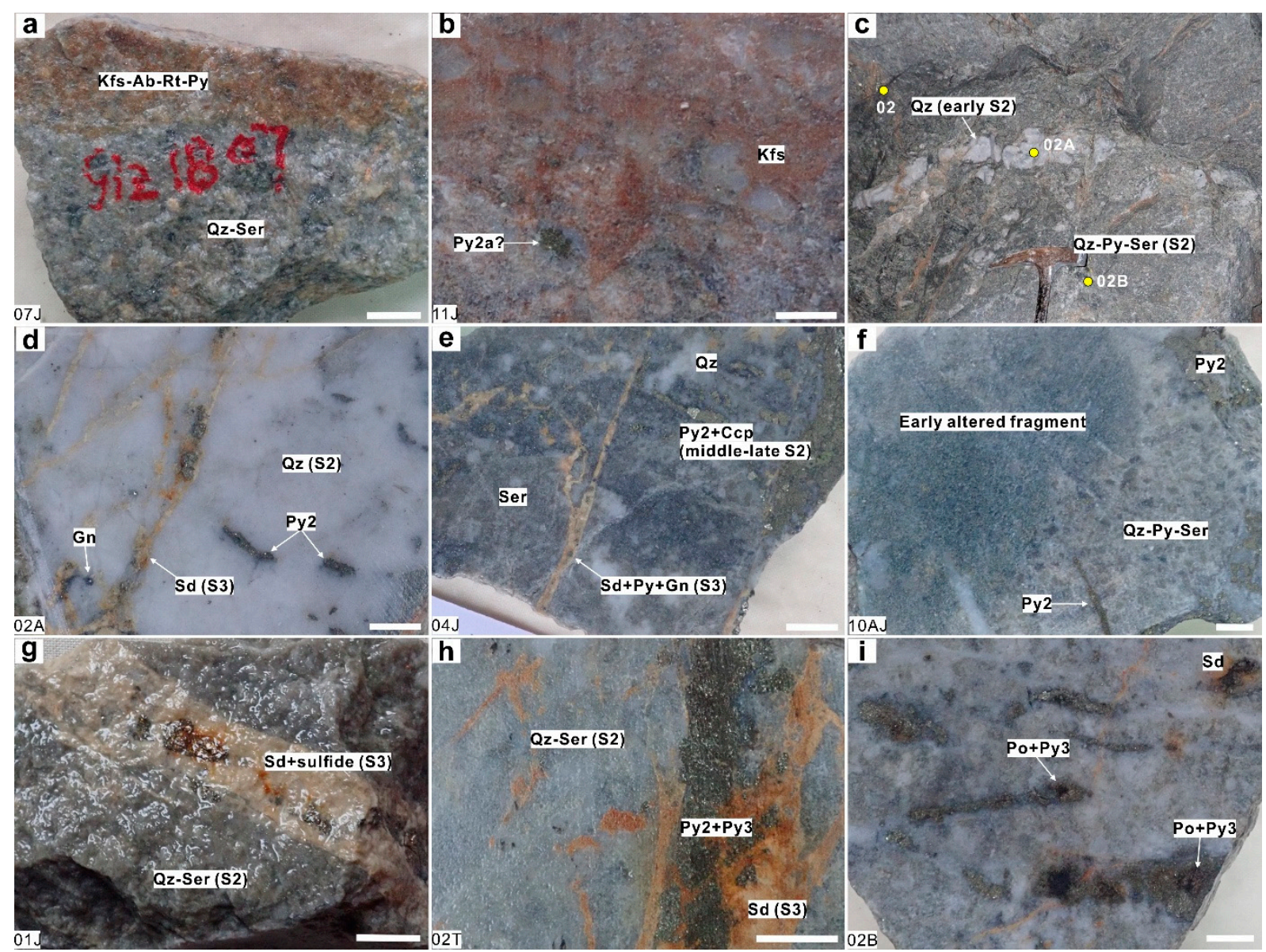

Figure 3. Photographs showing the occurrence of alteration and mineralization of the Sizhuang deposit. (a) and (b) K-feldspar-albite altered Linglong granite overprinted by early-phase sericitization and silicification. (c) Fractured white quartz vein cemented by intense quartz-sericite-pyrite alteration. (d) Pyrite aggregates mainly occurring as veinlet form in white quartz, which is crosscut by late siderite-pyrite vein. (e) Quartz-sericite-pyrite altered rocks exhibiting a breccia texture. (f) Early altered rocks replaced by late quartz-pyrite-sericite alteration showing a gradual relationship. (g) Quartz-sericite alteration crosscut by straight siderite-sulfide vein. (h) Fractured altered rocks and pyrite vein cemented by late siderite vein. (i) Pyrite vein locally replaced by late pyrrhotite and pyrite. Scale bar is $1 \mathrm{~cm}$. Ab albite; Ccp chalcopyrite; Gn galena; Kfs K-feldspar; Po pyrrhotite; Py pyrite; Qz quartz; Rt rutile; Ser sericite; Sd siderite.

Four mineral sequences have been identified in the Sizhuang deposit (Figure 4). Stage 1 is marked by pervasive K-feldspar-albite-rutile alteration and quartz-sericite alteration in the Linglong biotite granite (Figure 3a,b). The K-feldspar-albite-rutile alteration consists of albite, K-feldspar, sericite, hematite, rutile, and pyrite associated with the dissolution of plagioclase, biotite, titanite, and magnetite [55]. Quartz-sericite alteration with the mineral assemblage of sericite, quartz, and minor pyrite formed slightly later than K-feldspar-albiterutile alteration. Stage 2 (quartz-sericite-pyrite) is the chief gold mineralization period in Sizhuang. Early stage 2 is characterized by white quartz-pyrite veins that are commonly fractured or brecciated by structural deformation and subsequently cemented or crosscut (Figures 2 and $3 c, d$ ) by late alteration and veins. Middle-late stage 2 is marked by intense quartz-sericite-pyrite alteration that almost totally replaced the rock-forming minerals in the host rocks (Figure 3e) or early alteration minerals (Figure 3f). Hydrothermal minerals in this stage include grey quartz, sericite, pyrite, as well as minor siderite, chalcopyrite, and electrum (Figure 4). Stage 3 comprises quartz-siderite-polymetallic sulfide veins, stockworks, or veinlets that overprint on quartz-sericite-pyrite alteration (Figure 3g-i). Sulfide aggregates (pyrite, pyrrhotite, marcasite, chalcopyrite, and galena) of stage 3 occur in the middle of the veins (Figure 3g), suggesting they formed late in the paragenesis. 
Pyrrhotite as the early phase of stage 3 usually replaces previously formed pyrite (Figure 3i). Barite, magnetite, and marcasite were mainly precipitated in late stage 3 (Figure 4; [57]). Minor Te-Bi minerals are also formed in polymetallic sulfide veins [58]. Stage 4 is dominated by quartz and calcite, representing the post-ore stage. The Jiaodong Group amphibolite in the hanging wall displays K-feldspar, sericite, chlorite, and pyrite alteration, but no clear cross-cutting relationship was observed with the other mineralization phases.

\begin{tabular}{|c|c|c|c|c|}
\hline Minerals & Stage 1 & Stage 2 & Stage 3 & Stage 4 \\
\hline Quartz & & & & \\
\hline K-feldspar & & & & \\
\hline Albite & & & & \\
\hline Rutile & - & & & \\
\hline Sericite & ….... & & - & \\
\hline Siderite & & & & \\
\hline Barite & & & $\longrightarrow$ & \\
\hline Calcite & & & & \\
\hline Pyrite & Py1 & $\underbrace{\text { Py2a }}_{\text {Py2b }}$ Py2c & $\overbrace{}^{\text {Py3 }}$ & \\
\hline Chalcopyrite & & & & \\
\hline Electrum & $\cdots \cdots$ & 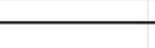 & - & \\
\hline Invisible Au & $\ldots$ & $\ldots$ & & \\
\hline Galena & & & & \\
\hline Sphalerite & & & & \\
\hline Pyhorrtite & & & 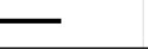 & \\
\hline Marcasite & & & $\longrightarrow$ & \\
\hline Hematite & ........ & & & \\
\hline Magnetite & & & $\cdots$ & \\
\hline
\end{tabular}

Figure 4. Paragenetic sequence of major minerals in the Sizhuang deposit.

\section{Samples and Analytical Methods}

A total of 22 polished sections were prepared from 19 samples collected from the Sizhuang deposit. Samples were collected at the $-128 \mathrm{~m}$ level on the 288 exploration line (Figure 2a,b). These were used for optical microscopy and in situ analysis by electron probe micro-analyzer (EPMA) and laser ablation-inductively coupled plasma-mass spectrometry (LA-ICP-MS). The detailed sample locations are shown in Figure 2c.

Pyrite grains were etched for about 20-60 s using bleach (sodium hypochlorite solution, $8-10 \% \mathrm{NaClO}$ ) to reveal internal textures. After etching, the samples were rinsed immediately with water and oven-dried.

Backscattered electron (BSE) imaging was carried out with a 1720 EPMA of Shimadzu Corporation at the Central South University, China. The accelerating voltage was set as $15 \mathrm{kV}$ and the current was adjusted in the range from $5 \mathrm{nA}$ to $150 \mathrm{nA}$ based on the composition difference in objective minerals. The brightness and contrast were manually adjusted to present the clearest images.

The LA-ICP-MS analysis of sulfide minerals was conducted utilizing an NWR ablation system $(\lambda=193 \mathrm{~nm})$ coupled to an ICAP RQ ICP-MS instrument to acquire ion-signal intensities at the Guangzhou Tuoyan Analytical Technology Co., Ltd., Guangzhou, China. 
Helium was used as a carrier gas. Line scans for sulfide LA-ICP-MS mapping were carried out using a $10 \mu \mathrm{m}$ spot at $20 \mathrm{~Hz}$ and a scan speed of $30 \mu \mathrm{m} / \mathrm{s}$. The spot size and analysis frequency for spot analysis were set to $40 \mu \mathrm{m}$ and $8 \mathrm{~Hz}$, respectively. Each spot analysis incorporated a $15 \mathrm{~s}$ background acquisition, $35 \mathrm{~s}$ sample ablation, and $30 \mathrm{~s}$ washout time. Analyses were calibrated against three reference materials (NIST 610, GSE-1G, and GE7). The trace element mapping was calibrated against the reference materials GSE-1G and NIST 610. Iron content determined by 1720 EPMA of Shimadzu Corporation (acc. Voltage $15 \mathrm{kV}$, probe current $20 \mathrm{nA}$, and spot size $5 \mu \mathrm{m}$ ) was chosen as the internal standard for pyrite. All LA-ICP-MS data were processed using the software Iolite (v3, School of Earth Sciences, The University of Melbourne, Melbourne, Australia) (http://iolite-software.com). The data for the standard MASS-1, which was used as an unknown sample for quality control, were mostly within $5 \%$ of in-house monitored concentrations. The Sizhuang sulfide had many monitor elements (e.g., As, $\mathrm{Co}, \mathrm{Ag}, \mathrm{Pb}$, Bi, etc.) with orders of magnitude variations (RMS (root mean squared) up to 3698; Table S1) resulting in large variations of uncertainties (RMS 0.013-343) and thus the analytical uncertainty was insignificant relative to sample heterogeneity. The detection of limits for monitored elements is listed in Table S1.

\section{Results}

\subsection{Pyrite Textures}

Based on host rocks, mineral assemblages, textures, and relative relationships (e.g., overgrowth, containing, and filling), three types of pyrite in the Sizhuang deposit have been recognized in this study. The earliest generation of pyrite (Py1; Figure 4) is distributed as disseminated grains in K-feldspar-albite-rutile and quartz-sericite altered rocks of stage 1. The Py1 is spatially associated with altered Fe-bearing minerals (e.g., biotite). The Py1 crystals associated with different alteration share similar textural features such as fine- to middle-sized grains (mostly $<300 \mu \mathrm{m}$ in diameter) euhedral to subhedral (Figure 5a-d) and homogeneous BSE images. Minor amounts of Py1 grains occurred as coarse-grained cubic crystals [55]. Py1 locally displays porous textures due to the trapping of silicate mineral inclusions during growth (Figure 5d). Minor fine-grained free electrum coexists with Py1 grains and sericite.

Stage 2 pyrite (Py2) occurs as veins or massive accumulations in the quartz-sericitepyrite alteration (Figures $3 \mathrm{~d}-\mathrm{f}$ and $5 \mathrm{e}$ ). It consists of coarse- to medium-grained, subhedral to anhedral grains, with cataclastic textures (Figure 5e-k). They display complex textures since they are typically contained, filled, or sealed by later addition of quartz, siderite, and sulfide. Early-phase Py2 (Py2a) occurs as irregular cores up to $150 \mu \mathrm{m}$ across that are enclosed by zoned Py2 (Py2b; Figure 5f,g). Py2b is the most common Py2 and is subhedral to anhedral and from tens to hundreds of $\mu \mathrm{m}$ across (Figure $5 \mathrm{f}-\mathrm{k}$ ). The early Py $2 b$ has narrow compositionally inhomogeneous growth bands revealed by etching or BSE imaging, whereas late Py2b generally develops wide or no zonation (Figure $5 \mathrm{f}-\mathrm{h}$ ). Py $2 b$ grains usually form cataclastic textures due to frequent microstructural deformation and are overgrown by late-phase pyrite (Figure 5i,j and Figure 6a). Py2c occurs as euhedral to anhedral fine to medium grains (mostly several to hundreds of $\mu \mathrm{m}$ in size). Py2c grains exhibit brighter colors in reflected light (Figure 5i) and BSE images (partly) than Py2b (Figure 5k). Metallic minerals coexisting with Py2 are mainly chalcopyrite and galena and occur as inclusions in crystals or veinlets filling fractures (Figure 5e,g,i,k). 


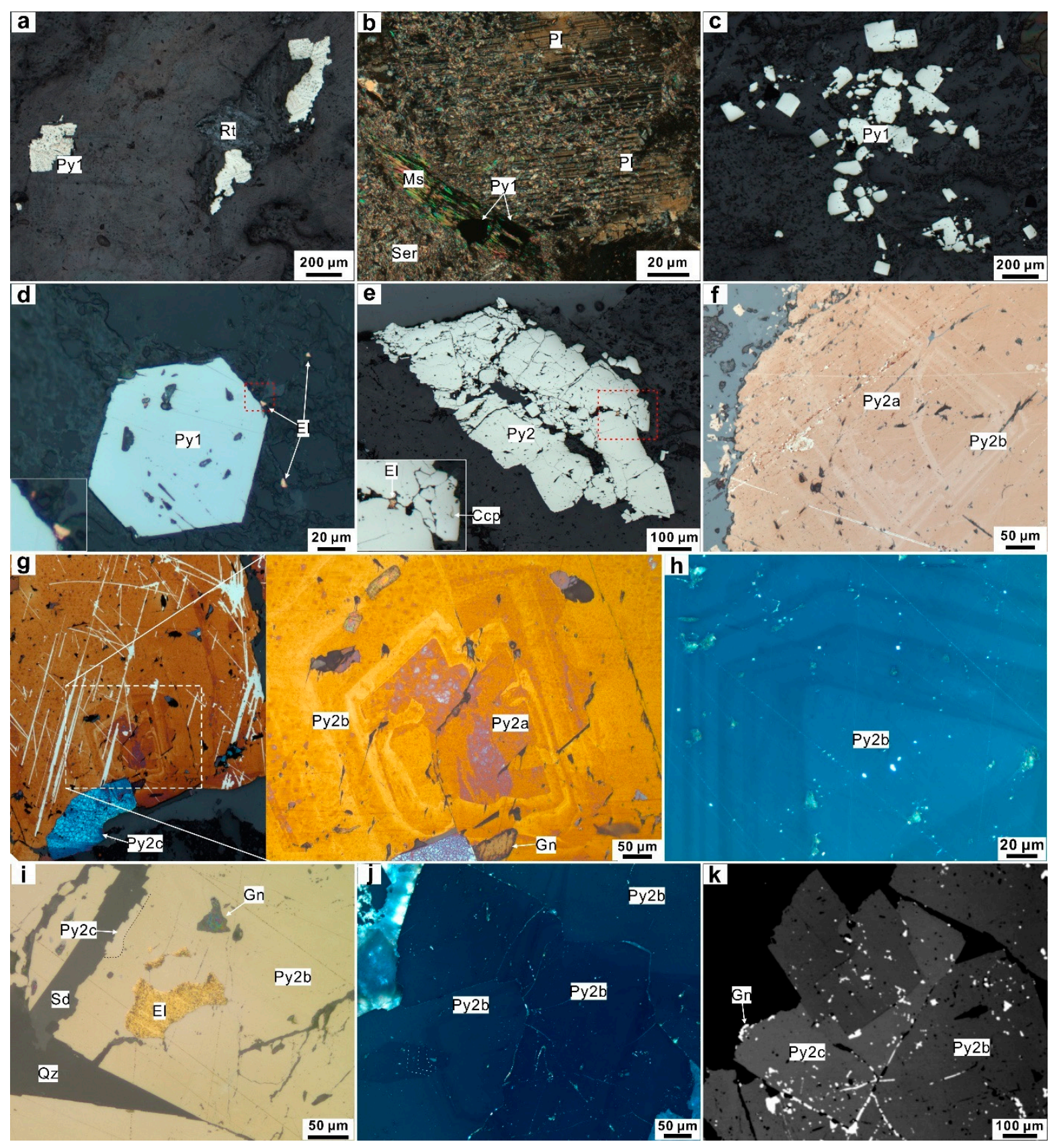

Figure 5. Reflected light (a,c-g,i), transmitted plane-polarized light (b) and crossed-polarized light (h,j) photomicrographs and backscattered electron (BSE) image (k) illustrating textures and mineral assemblages of Py1-2 in the Sizhuang gold deposit. (a) Earliest pyrite (Py1) as disseminated anhedral to subhedral grains with fine-grained rutile. (b) Intergrowth of Py1 and muscovite that totally replaced biotite. (c) Medium-grained euhedral to subhedral Py1 clusters in sericite altered rocks. (d) Py1 coexisting with free electrum. (e) Coarse-grained pyrite aggregates (Py2) associated with quartz vein, in which electrum occurs in the fractures of Py2. (f) Early formed pyrite (Py2a) as irregular core overgrowth by zoned pyrite (Py2b). Note the fractured Py2a-b was healed by late pyrite during pyrite growth. (g) NaClO-etched pyrite showing the formation sequence of several subtypes of Py2. The As-rich Py2c and galena are more susceptible to NaClO. Note the straight white line is caused by wiping rather than etching. (h) Py2b with the oscillatory zoning texture. (i) Py2b intergrown with electrum and galena and overgrown by Py2c with relatively white reflected-color (As-rich). (j) Py2 commonly underwent fracture-growth processes. (k) Py2c showing a lighter color in BSE images. Galena often occurs in the pyrite fractures or as filling into Py2. Ccp: chalcopyrite; El: electrum; Gn: galena; Ms: muscovite; Rt: rutile; Sd: siderite; Pl: plagioclase; Py: pyrite; Qz: quartz. 


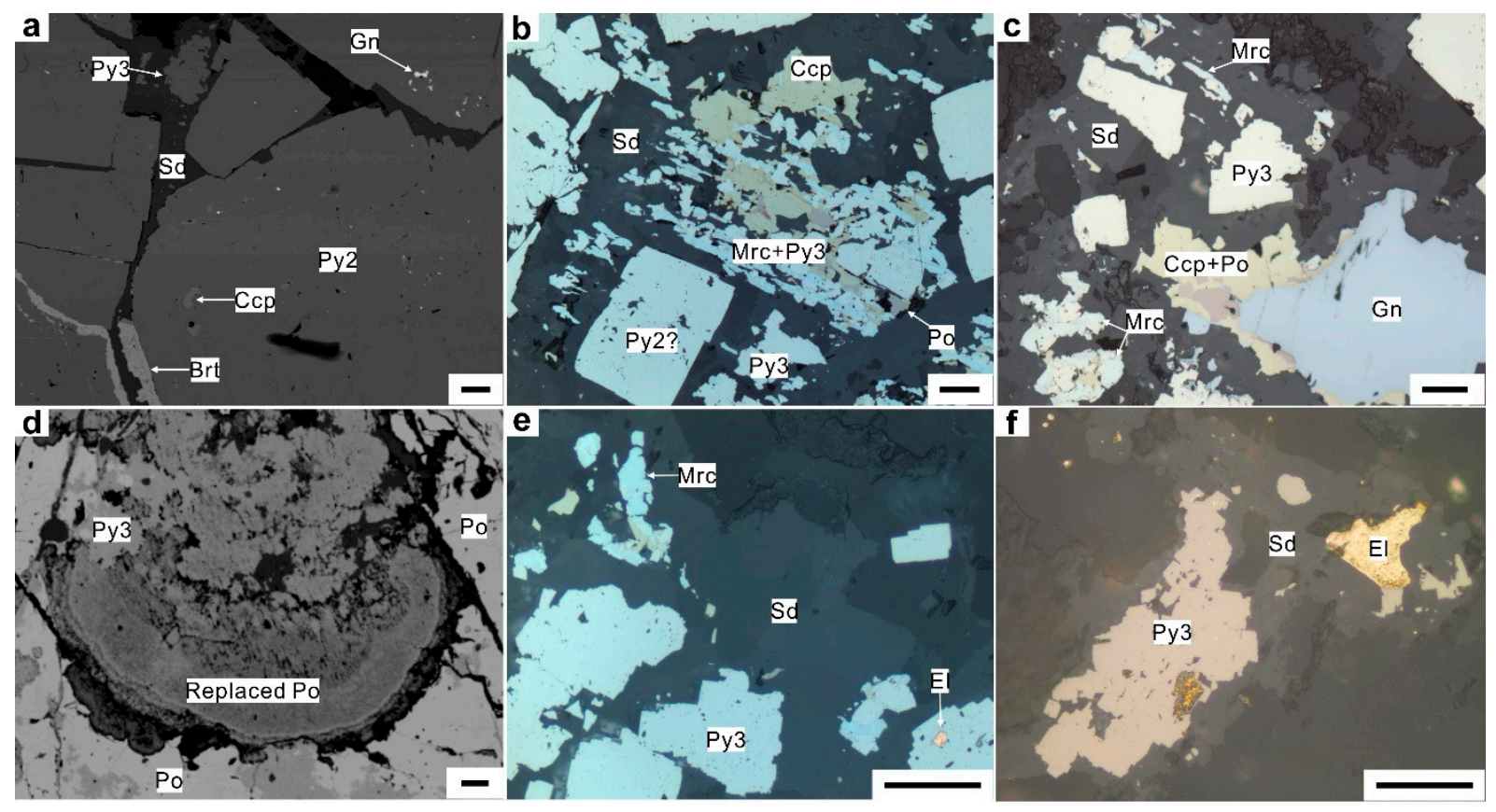

Figure 6. Reflected light (b,c,e,f) photomicrographs and BSE image (a,d) illustrating textures and mineral assemblages of Py3 in the Sizhuang gold deposit. (a) Fine-grained Py3, siderite, and barite filling into the fractures and interstice among euhedral Py2 crystals. (b,c) Typical mineral assemblage of Py3, marcasite, chalcopyrite, pyrrhotite, galena, and siderite in stage 3. Note marcasite formed slightly late than Py3, chalcopyrite, and pyrrhotite with respect to the replacement relationship. (d) Pyrrhotite locally or totally transformed as Py3 or colloform pyrite. (e) Electrum as inclusions within a Py3 grain. (f) Free electrum, Py3, and siderite of stage 3. Scale bar is $50 \mu \mathrm{m}$. Brt barite; Ccp chalcopyrite; El electrum; Gn galena; Mag magnetite; Mrc marcasite; Sd siderite; Po pyrrhotite; Py pyrite; Qz quartz.

The third generation of pyrite (Py3) is mainly distributed in stage 3 breccia and silicified rocks as aggregates or veinlets in carbonate-sulfide veins (Figure 6). Py3 is distinguished from early pyrite by its generally small size $(<100 \mu \mathrm{m}$ in size), anhedral to subhedral crystals, and siderite-marcasite-pyrrhotite assemblage (Figure 6a-d). The syn-mineral pyrrhotite is often replaced by Py3 (Figure 6d), indicating it formed before Py3, which in turn is replaced or overgrown by syn-stage marcasite (Figure 6e) or magnetite. Electrum is recognized as the inclusions within Py3 (Figure 6e) or free forms in siderite veins (Figure 6f).

\subsection{Pyrite Geochemistry}

Trace element chemistry of pyrite (Py1 $n=31, \operatorname{Py} 2 a n=16, \operatorname{Py} 2 b n=39, \operatorname{Py} 2 \mathrm{c} n=13$, Py3 $\mathrm{n}=19$ ) determined by LA-ICP-MS is listed in Table S1.

Disseminated pyrite (Py1) in stage 1 has higher concentrations of Co (36.7-237 ppm; data between the 25th and 75th percentiles in box-plot), Ni (28.8-172 ppm), and Te (from B.D.L (below detection limit) to $2.62 \mathrm{ppm}$ ) but lower $\mathrm{Cu}, \mathrm{Zn}, \mathrm{Ag}$, Sb, and $\mathrm{Tl}$ (Figures 7 and $8 \mathrm{a}$ ). Gold in Py1 ranges from B.D.L to $0.35 \mathrm{ppm}$, with a mean value of $0.04 \mathrm{ppm}$ (s.d. (standard deviation $)=0.06, \mathrm{n}=31)$ and correlates with $\mathrm{Co}(\mathrm{r}=0.717$; Figure $8 \mathrm{~b})$ and $\mathrm{Ni}$ $(\mathrm{r}=0.514$; Table S2). Silver concentrations of Py1 are markedly related to the concentrations of $\mathrm{Mn}, \mathrm{Pb}(\mathrm{r}=0.976)$ and $\mathrm{Bi}(\mathrm{r}=0.787)$. Cobalt and $\mathrm{Ni}$ are homogeneously distributed within Py1 grains (Figure 9a,b). Tungsten is mostly below the detection limit in Py1 grains and its contents in several spots are associated with Ti (Figures $8 c$ and 9a). 

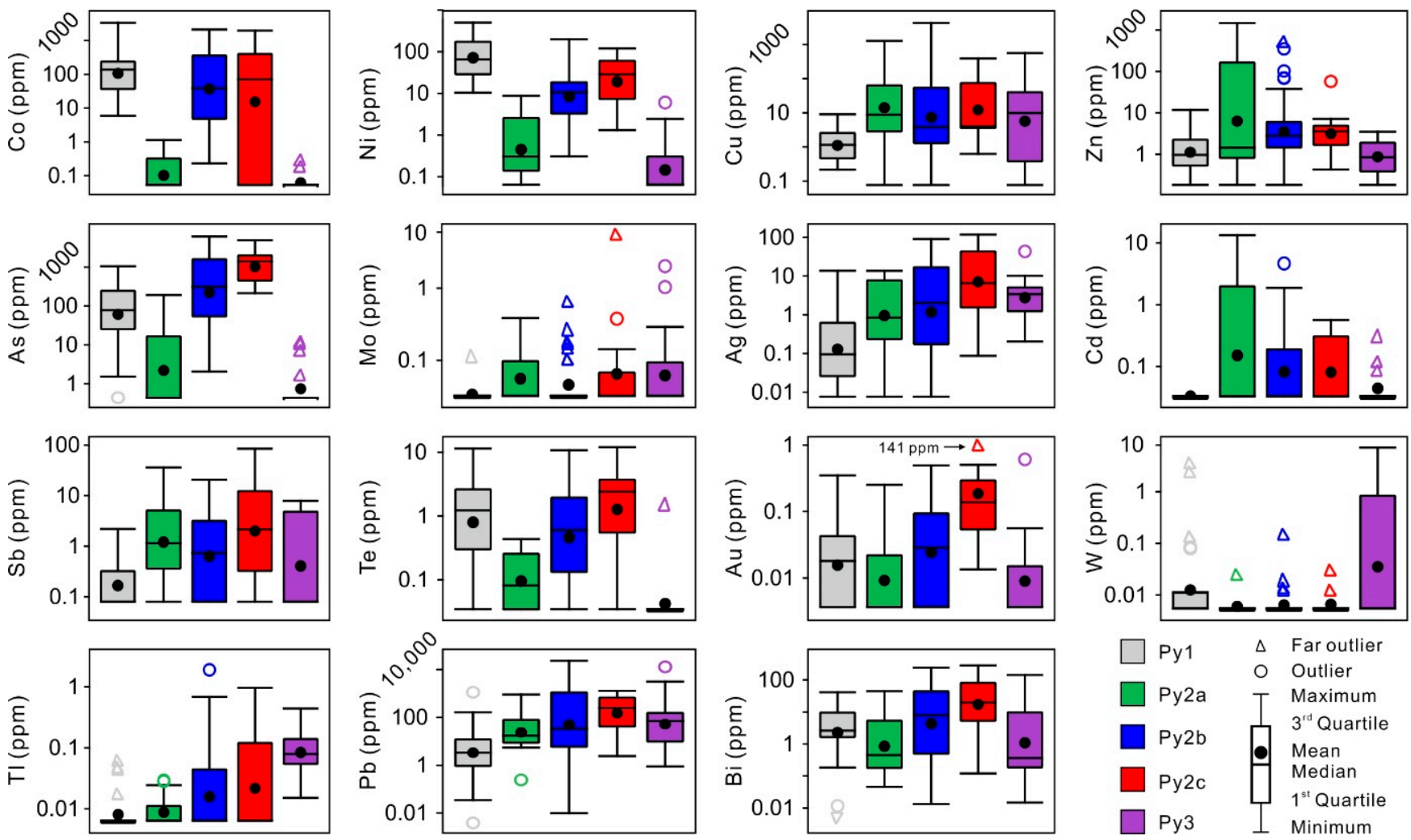

Figure 7. Comparative box-whisker plots showing the concentration of representative trace elements measured by laser ablation-inductively coupled plasma mass spectrometry (LA-ICP-MS) in pyrite from the Sizhuang gold deposit.

The Py2a is depleted in $\mathrm{Co}, \mathrm{Ni}, \mathrm{As}$, and Te and enriched in $\mathrm{Cu}, \mathrm{Mo}, \mathrm{Ag}, \mathrm{Cd}, \mathrm{Sb}$, and $\mathrm{Pb}$ relative to Py1. The concentrations of gold in Py2a are similar to Py1 but do not show any correlation with other elements (Table S2). The Py2a is characterized by low Co and As contents compared to Py2b-c (Figures 7 and 10). Zinc, Cd, and In are consistently variable during laser ablation of Py2a (Figure 9c), which is concordant with the high correlation coefficients (Table S2). Overall, the contents of $\mathrm{Ni}, \mathrm{As}, \mathrm{Ag}, \mathrm{Te}, \mathrm{Au}, \mathrm{Tl}, \mathrm{Pb}$, and $\mathrm{Bi}$ in the three types of Py2 gradually increase from Py2a to Py2c (Figure 7). Most trace elements (e.g., $\mathrm{Co}, \mathrm{Ni}, \mathrm{Cu}, \mathrm{As}, \mathrm{Pb}$, and $\mathrm{Bi}$ ) in $\mathrm{Py} 2 \mathrm{~b}$ have large variations (Figures 7 and 8). The growth zoning of Py $2 \mathrm{~b}$ revealed by $\mathrm{NaClO}$-etching is associated with $\mathrm{Co}$ and As content variations determined by LA-ICP-MS mapping (Figure 10). The concentrations of Au and Te are generally consistent with As in the oscillatory zonation (Figure 10), but are not shown in the binary plot of $\mathrm{Au}-\mathrm{Te}$ (Figure $8 \mathrm{f}$ ). The high-As bands of Py $2 \mathrm{~b}$ have highly variable $\mathrm{Cu}, \mathrm{Pb}, \mathrm{Bi}$, and/or $\mathrm{Ag}$ and $\mathrm{Sb}$ (Figure $9 \mathrm{~d}, \mathrm{e})$. The Py2c is characterized by relatively high $\mathrm{Ni}(7.35-60.3 \mathrm{ppm}), \mathrm{As}(449-1982 \mathrm{ppm})$, and $\mathrm{Au}(0.05-0.29 \mathrm{ppm})$ concentrations. Gold is positively correlated to As $(r=0.751)$ and $\mathrm{Te}(\mathrm{r}=0.426)$ in Py2b and $\mathrm{Ag}(\mathrm{r}=0.758)$ and $\mathrm{Bi}(\mathrm{r}=0.784)$ in Py2c, respectively (Table S2). The Py2c spot (PyL08) with the highest Au $(118 \mathrm{ppm})$ and $\mathrm{Ag}(140 \mathrm{ppm})$ concentrations exhibits parallel time-resolved profiles of $\mathrm{Au}$ and Ag (Figure 9f). 

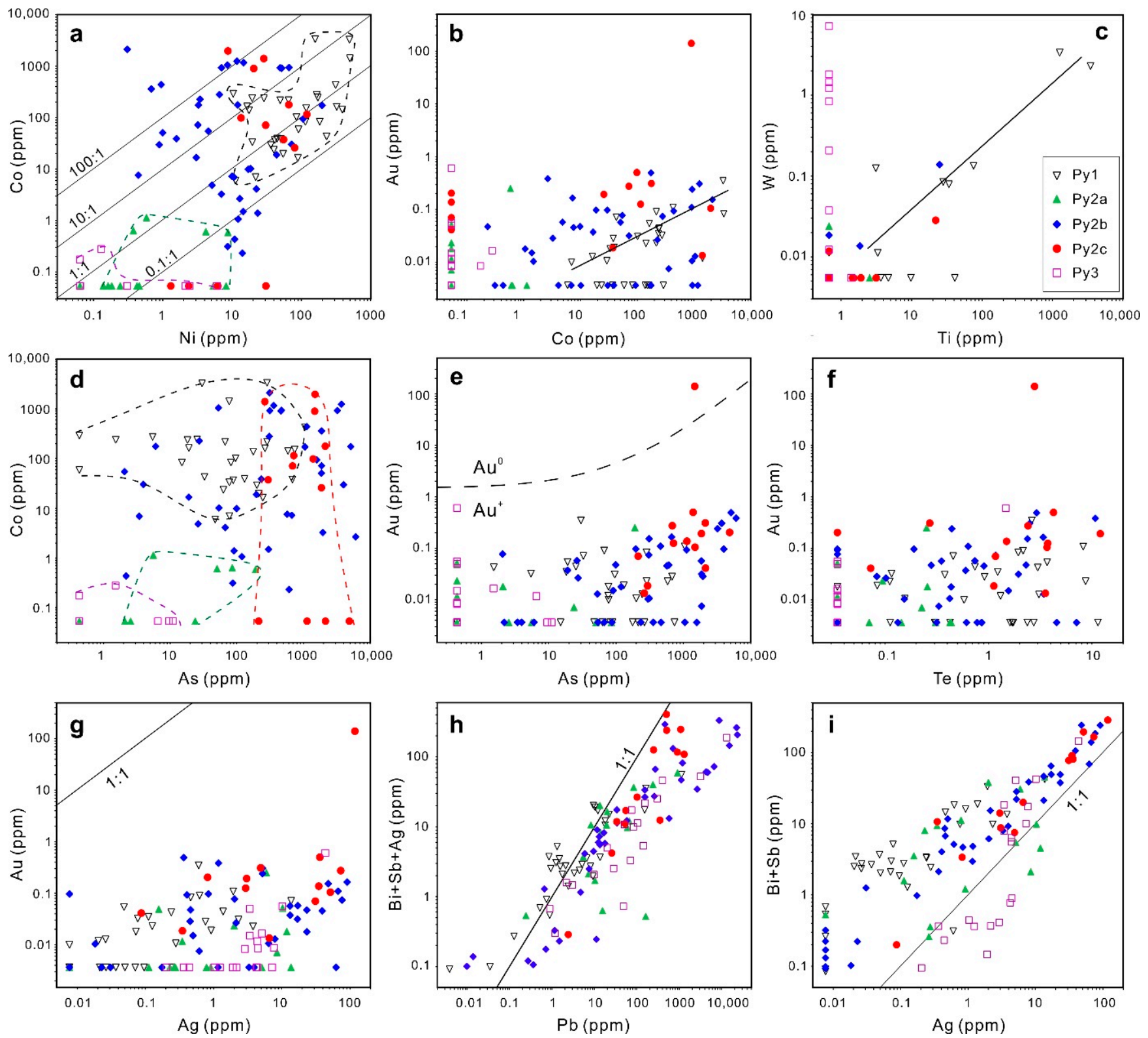

Figure 8. Binary plots of trace elements of the Sizhuang pyrite measured by LA-ICP-MS. (a) Ni vs. Co. (b) Co vs. Au. (c) Ti vs. W. (d) As vs. Co. (e) As vs. Au. (f) Te vs. Au. (g) Ag vs. Au. (h) Pb vs. Bi + Sb + Ag. (i) Ag vs. Bi + Sb. The dashed curve in e represents the solubility limit of $\mathrm{Au}$ as a function of As content determined by [59]. Note the legends in $8 \mathrm{c}$ are available for all subfigures. 

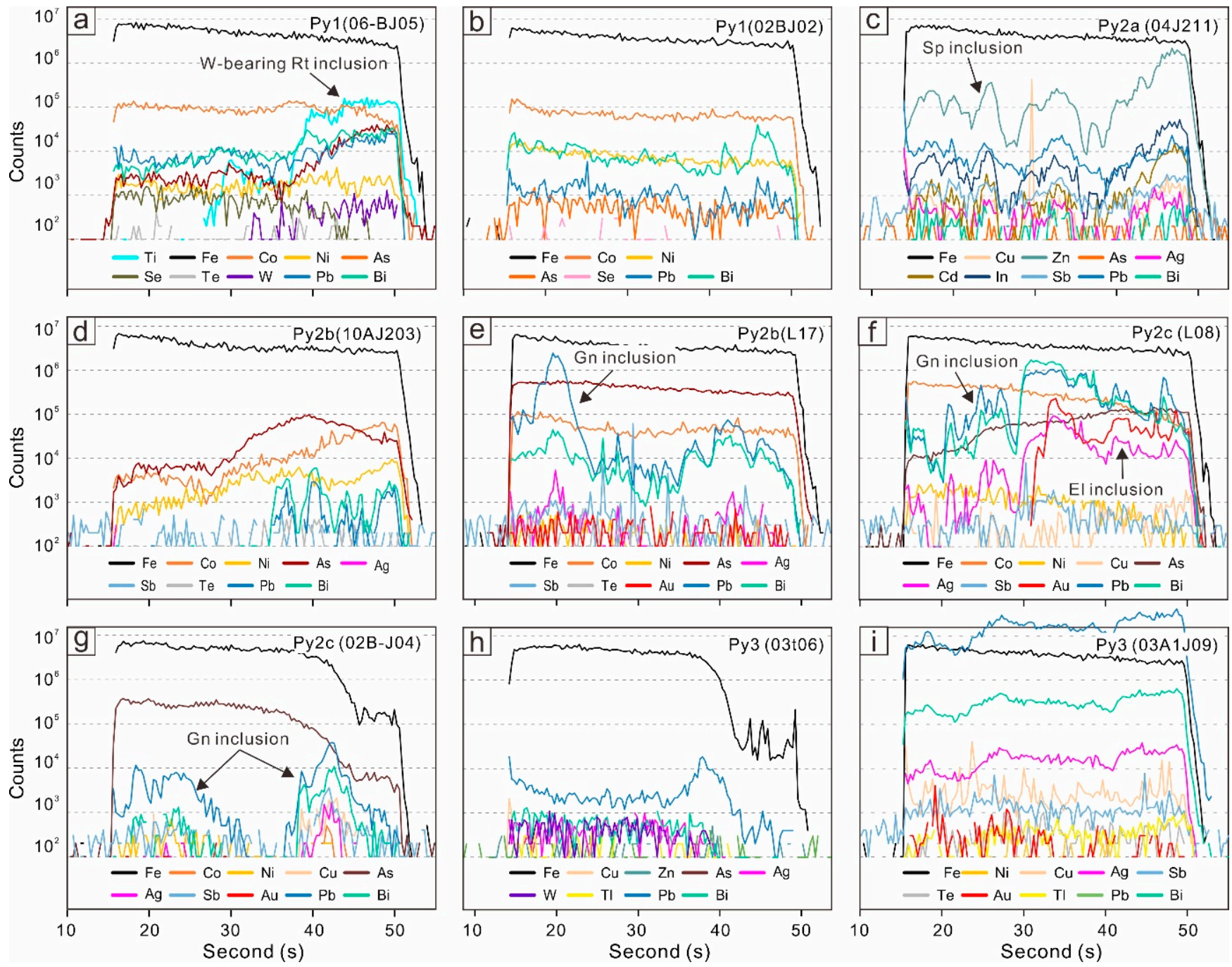

Figure 9. Representative time-resolved depth profiles of LA-ICP-MS analyses of pyrite (Py1: a,b, Py2a: c, Py2b: d,e, Py2c: $\mathbf{f , g}$, and Py3: h,i) from the Sizhuang gold deposit. El electrum; Gn galena; Rt rutile; Sp sphalerite.

The fine-grained pyrite (Рy3) in stage 3 sulfide-siderite veins is characterized by extremely low $\mathrm{Co}, \mathrm{As}, \mathrm{Cd}$, and Te and high $\mathrm{Tl}$ and $\mathrm{W}$ (Figures 8 and $9 \mathrm{~h}$ ). The concentrations of $\mathrm{Ni}, \mathrm{Zn}$, and $\mathrm{Au}$ in Py3 are generally lower than in Py2 grains. Lead, $\mathrm{Bi}$, and Ag signals are relatively consistent and locally flat in Py3 spots (Figure 9h,i). Correlations also exist between $\mathrm{Au}$ and $\mathrm{Ag}-\mathrm{Pb}-\mathrm{Bi}$ (Table S2). 

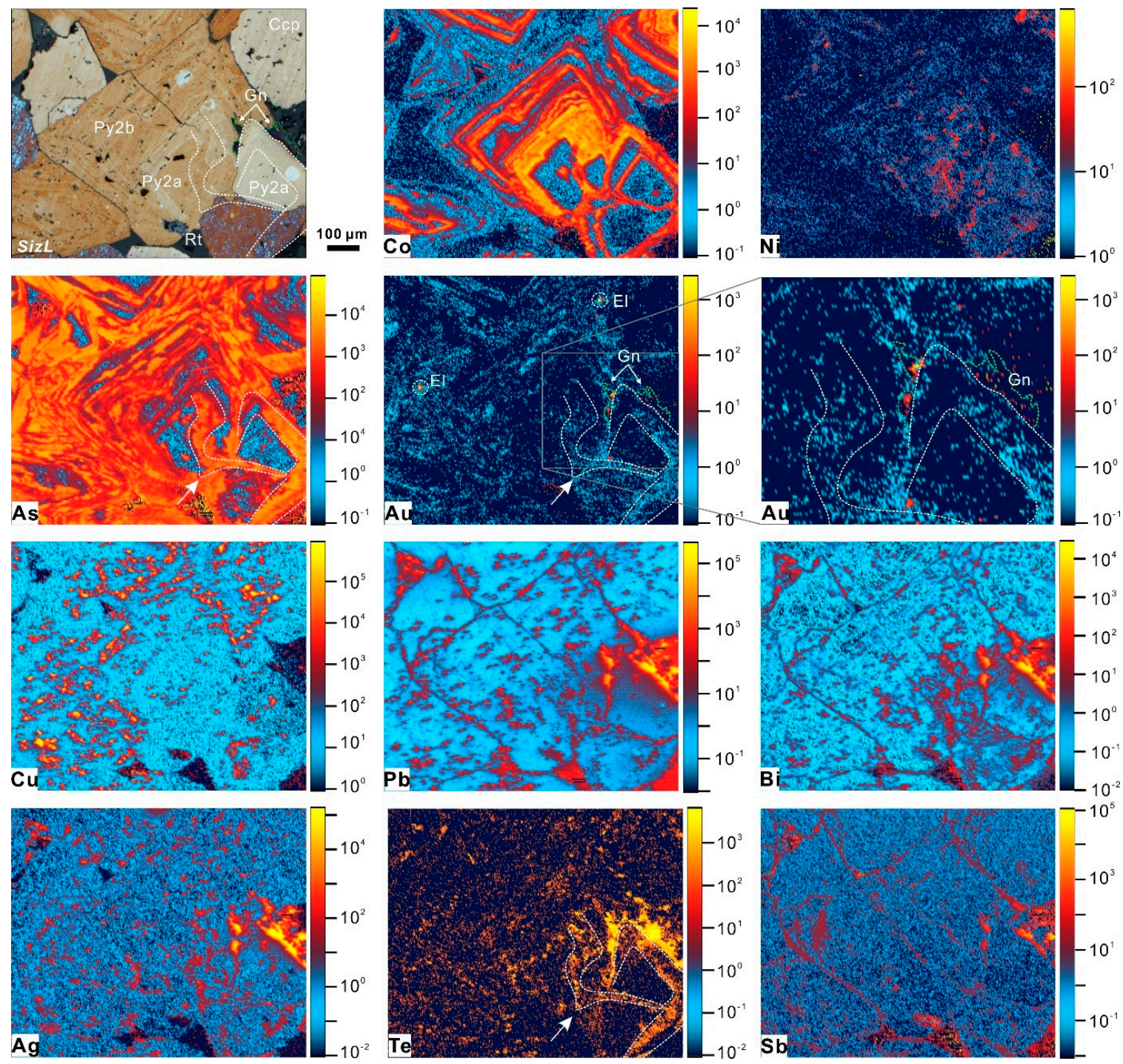

Figure 10. Reflected-light and LA-ICP-MS mapping images of representative NaClO-etched Py2 grains from the sample SizL illustrating the general variation of trace elements (in ppm). Early-phase Py $2 b$ is Co-rich relative to late-phase Py $2 b$ that is enriched in As and Au. Note high Au and Te concentrations occur in the local high-As areas in Py2b (marked by arrows and white dashed line). Galena grains (green dashed line) are relatively enriched in Bi, Au, Ag, Sb, and Te. Note there is much fine-grained gold within the galena.

\section{Discussion}

\subsection{Gold Occurrence and Its Controls}

Gold can occur in pyrite as free Au-bearing mineral inclusions (e.g., native gold, electrum, petzite, and calaverite) or as solid solution in the pyrite lattice [26,33,35,46,59-63]. Gold in Py1 is positively correlated with $\mathrm{Co}(\mathrm{r}=0.717)$ and $\mathrm{Ni}(\mathrm{r}=0.514$; Table S2). The ionic radii of octahedrally-coordinated $\mathrm{Fe}^{2+}, \mathrm{Co}^{2+}$, and $\mathrm{Ni}^{2+}$ are $0.92 \AA, 0.885 \AA$, and $0.83 \AA$, respectively $\left(\mathrm{Co}^{3+} 0.75 \AA ; \mathrm{Ni}^{3+} 0.74 \AA\right.$ ), whereas that of $\mathrm{Au}^{+}$is $1.51 \AA$ [64]. Therefore, the equivalent substitution of $\mathrm{Fe}^{2+} \leftrightarrow \mathrm{Co}^{2+}$ or $\mathrm{Ni}^{2+}$ is more feasible for pyrite and coupled substitution of the three elements (e.g., $2 \mathrm{Fe}^{2+} \leftrightarrow \mathrm{Co}^{3+} / \mathrm{Ni}^{3+}+\mathrm{Au}^{+}$) is less likely. The much lower Au concentrations (from B.D.L to $0.35 \mathrm{ppm}$ ) relative to Co (36.7-237 ppm) and Ni (28.8-172 ppm) also exclude the Au entrance into Py1 by the coupled substitution of octahedrally-coordinated $\mathrm{Fe}^{2+}$. Arsenic incorporation into the pyrite structure can distort the crystal structure, resulting in the possibility of $\mathrm{Au}^{+}$entering into pyrite [33,59]. Hence the empirical solubility limits accounting for As contents in pyrite allow the assertion, in 
most cases, that the $\mathrm{Au}$ is present as inclusions $\left(\mathrm{Au}^{0}\right)$ or in solid solution form $\left(\mathrm{Au}^{+}\right)$. All Py1 grains are below the lowest limit of Au-saturation proposed by [59], suggesting gold is dominantly found in the Py1 crystal lattice. The gold occurrence within Py1 grains is, thus, likely associated with As incorporation.

Minor electrum grains were observed in close association with Py1 (Figure 5d). Py1 is disseminated distributed in the K-feldspar-albite-rutile and quartz-sericite altered rocks and associated with the alteration of mafic minerals, especially biotite (Figure 5b). The occurrence is comparable to the early-phase pyrite in the Xincheng gold deposit in the Jiaojia belt [18], implying that Py1 was generated as a result of the preferential sulfidation of iron-rich minerals (e.g., biotite), during which the Fe can consume the reduced sulfur $\left(\mathrm{Fe}^{2+}+2 \mathrm{HS}^{-} \rightarrow \mathrm{FeS}_{2}+\mathrm{H}_{2}\right)$ causing the precipitation of pyrite from hydrothermal solutions. Overall, ore-forming fluids of the Sizhuang gold deposit represented a low salinity $\mathrm{H}_{2} \mathrm{O}$ $\mathrm{CO}_{2}-\mathrm{NaCl} \pm \mathrm{CH}_{4}$ system $[58,65]$. Gold is transported as Au-bearing complexes ( $\mathrm{Au}(\mathrm{HS})_{2}{ }^{-}$) in such a fluid system [66]. Thus, the reducing effect of iron minerals in the wall rocks on migrating hydrothermal fluids which can potentially lead to the precipitation of sulfides and the destabilization of sulfur-complexes, causing the synchronous gold deposition related to Py1.

The major types of Py 2 containing gold are Py $2 \mathrm{~b}$ and Py2c. The analyzed Py $2 \mathrm{~b}$ and Py2c grains (except for L08-02) were plotted below the Au-saturation line (Figure 8e), probably also suggesting the incorporation of refractory Au as Py1. Our trace element dataset shows a generally positive association between $\mathrm{Au}$ and As in the Sizhuang pyrite (Figures $8 \mathrm{e}$ and 10), especially for the zoned Py2b $(\mathrm{r}=0.751$; Table S2). This observation strongly suggests that structurally bound $\mathrm{Au}$ associated with As incorporation exists in these samples. Only the pyrite analyses of No. L08-02 reflects the existence of Au-bearing mineral inclusions (i.e., electrum). Such an interpretation is supported by the parallel timeresolved depth profiles of $\mathrm{Au}$ and $\mathrm{Ag}$ in Figure 9f. Notably, the existence of Au-bearing inclusions (e.g., electrum and native gold) in Py2 are detected in the LA-ICP-MS mapping (Figure 10), but these pyrite grains are indicated the form of $\mathrm{Au}^{+}$in Figure 8e. Our data reveal the correlation among Au, Ag, and Bi in Py2c (Table S2) and the Au signal is parallel to that of the other two elements. This association is either attributed to the geochemical affinity among $\mathrm{Au}, \mathrm{Ag}$ and $\mathrm{Bi}$ or metals residual in fluids after Py $2 \mathrm{~b}$ crystallization.

Py3 has extremely low As contents (mostly below detection limit), meaning no significant incorporation of $\mathrm{Au}^{+}$resulting from As substitution in pyrite (inference from $\mathrm{As}-\mathrm{Au}$ bi-plots). Gold in Py3 shows significant correlation with $\mathrm{Ag}$, $\mathrm{Pb}$, and $\mathrm{Bi}$ (Table S2; Figure 9i) that are contained in galena inclusions by substitution mechanisms of $\mathrm{Ag}^{+}+(\mathrm{Sb}, \mathrm{Bi})^{3+}$ $\leftrightarrow 2 \mathrm{~Pb}^{2+}$ or $(\mathrm{Ag}, \mathrm{Tl}, \mathrm{Cu})^{+}+(\mathrm{Sb}, \mathrm{Bi})^{3+} \leftrightarrow 2 \mathrm{~Pb}^{2+}[67,68]$. The positive correlation thus likely reflects the gold storage with galena, which is consistent with the pyrite LA-ICP-MS mapping results that galena contains much fine-grained gold (Figure 10). Previous studies have shown that galena crystal can contain tens to several hundred ppm of gold $[61,69,70]$ and it is also determined as the most favorable sulfide matrix (except for arsenopyrite) for locating gold (Au solubility up to $240 \mathrm{ppm}$ ) due to the high metallicity of chemical bond [61]. Besides, galena can capture additional gold by absorption of elements in crystal boundaries during crystallization in terms of heteroepitaxial structures [61,71]. The association of $\mathrm{Au}$ with $\mathrm{Ag}, \mathrm{Pb}$, and $\mathrm{Bi}$ most likely reflects the controls on gold enrichment from galena. The close relationship between gold and galena in the Jiaodong-type gold deposits was documented in $[18,72]$ and our recent works $[73,74]$, implying a common function of galena for gold mineralization. Apparently, galena should be reasonably estimated as a gold concentrator at the Jiaodong-type gold deposits.

\subsection{Fluid Evolution Recorded by Pyrite Compositions}

The incorporation of trace elements into pyrite is closely associated with complex fluid conditions, including fluid source, composition, and nature (e.g., temperature, pressure, $\mathrm{pH})$, and element partition among co-crystallization minerals or fluids [29,33,40,41,75-77]. The earliest generation of pyrite (Py1) has relatively high concentrations of $\mathrm{Co}$ and $\mathrm{Ni}$, 
and low $\mathrm{Cu}, \mathrm{Zn}, \mathrm{Ag}, \mathrm{Sb}$, and $\mathrm{Tl}$ (Figure 7), similar to the Xincheng pyrite [18]. Co- and $\mathrm{Ni}$-rich pyrite grains are widely reported in the early stages of hydrothermal systems with relatively high-temperature conditions $[26,29-31,78,79]$. Major factors favoring the enrichment of $\mathrm{Co}$ and $\mathrm{Ni}$ relative to other metals in pyrite in hydrothermal systems include high fluid temperatures [80-82] and/or special host rock composition (e.g., mafic to ultramafic lithology or metasedimentary; $[83,84])$. Due to the granite as host rocks for the Sizhuang gold deposits, the host rocks maybe less important for the Co and Ni enrichment in Py1. Two-feldspar (K-feldspar and plagioclase) thermometer calculation and fluid inclusion analysis of the K-feldspar alteration in the Sizhuang deposit suggest the early alteration happened under high-temperature $\left(\sim 300\right.$ to $\left.450{ }^{\circ} \mathrm{C}\right)$ conditions $[58,65,85]$. The quartz $\mathrm{H}-\mathrm{O}$ isotopes from stage 1 are close to the primary magmatic water source region [55]. Thus, high Co concentrations in Py1 suggest early high-temperature fluids that were likely derived from deep magmatic intrusions.

Considering the relative late sequence (decreased temperature) of polymetallic-style mineralization in hydrothermal gold systems, rare Au deposition at high-temperature conditions, and a geochemical affinity of As for low density and low salinity fluids [27,86,87], the diagrams of $\mathrm{Cu} / \mathrm{Ni}$ vs. $\mathrm{Au} / \mathrm{Co}[78,88]$ and $\mathrm{As} / \mathrm{Ni}$ vs. $\mathrm{Au} / \mathrm{Co}$ potentially reflect the progressive evolution involving the decreasing temperature conditions (likely caused by external cool fluid ingress [89]) in a magmatic hydrothermal system (Figure 11). The diagrams are consistent with the pyrite geochemistry and the changes of fluid conditions in the Sizhuang gold deposit, supporting the dominant controls of temperature on the entry of $\mathrm{Co}$ and $\mathrm{Ni}$ into early pyrite in the Sizhuang and other Jiaodong-type gold deposits (e.g., Xincheng, China). 

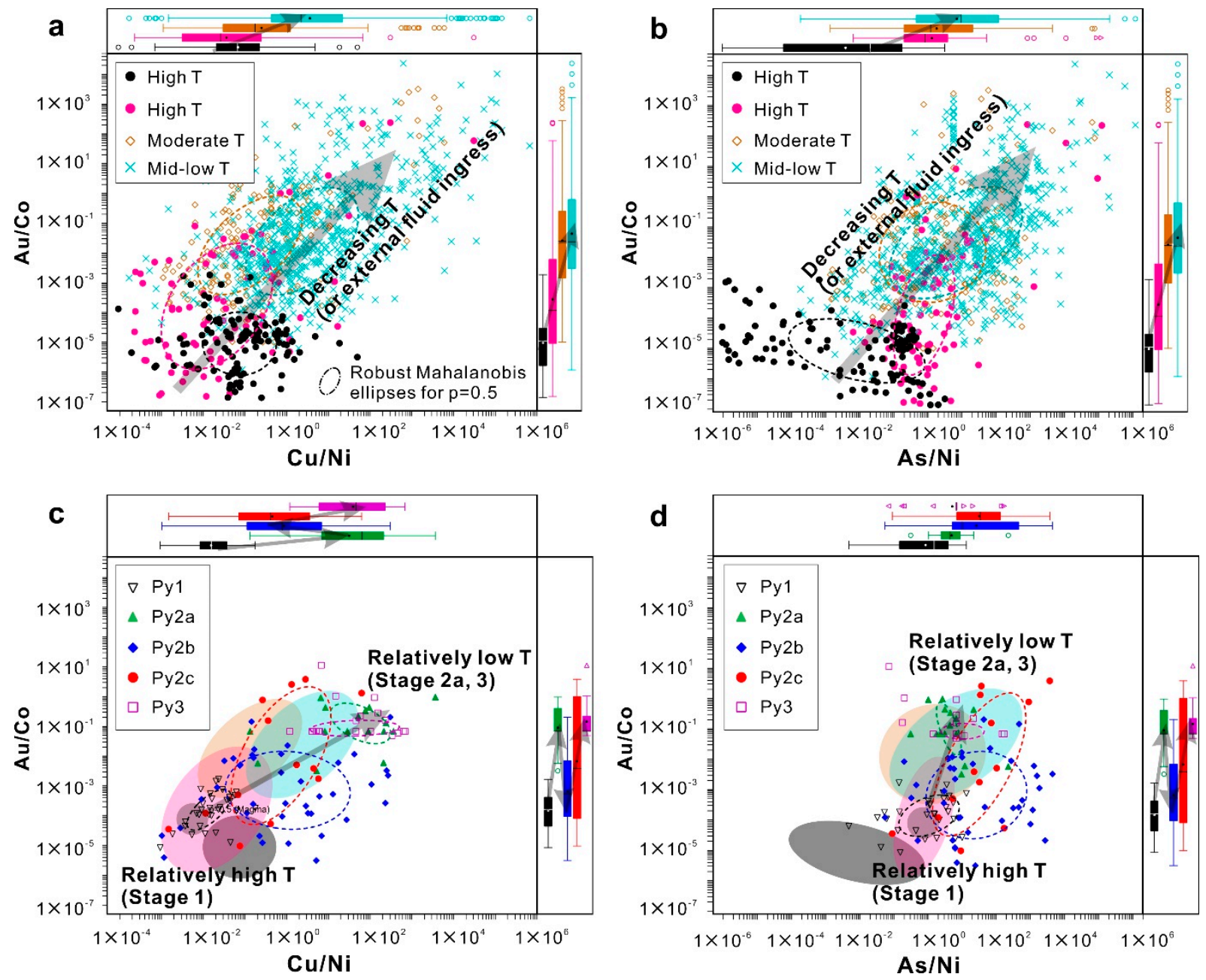

Figure 11. Binary plots of $\mathrm{Cu} / \mathrm{Ni}$ vs. $\mathrm{Au} / \mathrm{Co}(\mathbf{a}, \mathbf{c})$ and $\mathrm{As} / \mathrm{Ni}$ vs. Au/Co $(\mathbf{b}, \mathbf{d})$ of pyrite. Pyrite with high T (temperature, black, $n=126)$, high $T$ (purple, $n=86)$, moderate $T(n=184)$, and mid-low $T(n=720)$ is related to magmatic sulfide deposits $\left(\mathrm{T} \mathrm{350-600}{ }^{\circ} \mathrm{C}\right.$ ), K-silicate alteration of porphyry deposits $\left(\mathrm{T} 400-500{ }^{\circ} \mathrm{C}\right.$; [89]), transition from porphyry to epithermal (D-type vein or phyllic-host; $\mathrm{T}<400^{\circ} \mathrm{C}$ ), and epithermal deposits $\left(\mathrm{T}<300^{\circ} \mathrm{C}\right)$, respectively. The arrows show a temperature variation or external waters ingress estimated by $\mathrm{Cu} / \mathrm{Ni}, \mathrm{As} / \mathrm{Ni}$, and $\mathrm{Au} / \mathrm{Co}$ values. Data were collected from $[26,31,35,78,79,88,90-92]$.

The Py2a is depleted in most pyrite-compatible elements (e.g., $\mathrm{Co}, \mathrm{Ni}$, and $\mathrm{As}$ ) and has higher $\mathrm{Cu} / \mathrm{Ni}, \mathrm{As} / \mathrm{Ni}$, and $\mathrm{Au} / \mathrm{Co}$ ratios relative to Py1 (Figure 11), likely implying a decreasing temperature condition during early stage 2 . The Py2a of the early quartzsericite-pyrite stage (stage 2) is mainly found in white quartz veins or breccias (Figure $3 c, d)$, which typically have high fluid/rock ratio conditions (e.g., $[93,94])$. The documented $\mathrm{H}-\mathrm{O}$ isotope shift to meteoric waters at the time of stage $2[55,58,65]$ suggests the large meteoric water ingress at Sizhuang during stage 2. Thus, the external fluid influx likely decreased the fluid temperature and concentrations of metals and metalloids, resulting in the element-poor pyrite (Py2a).

The Py $2 b$ has high but variable trace elements relative to Py2a (Figure 7$)$. The early phase of Py2b had significantly higher Co concentrations, while the late phase of Py $2 b$ was $\mathrm{As}(-\mathrm{Au})$ rich (Figure 10), combined with the similar mineral assemblages (Figure 4 ) and closely spatial relationships (Figure $5 \mathrm{f}, \mathrm{g}$ ), meaning the transition of fluids from Co-rich to As-rich occurred during the middle of stage 2, as stated in [44]. As discussed above, the high Co concentration likely reflects higher temperatures, suggesting the influx of a new pulse of magmatic derived fluids during middle stage 2. In contrast to $\mathrm{Co}$, arsenic preferentially partitions into low density and low salinity aqueous fluids $[27,86,87]$. 
Taking account of the decreasing $\delta \mathrm{D}_{\mathrm{SMOW}}$ and $\delta \mathrm{O}_{\mathrm{H} 2 \mathrm{O}}$ over time at Sizhuang [58,65], the As enrichment in late-phase fluids during middle stage 2 was possibly promoted by the decreasing density, salinity, and temperature of ore-forming fluids in response to the input of diluted meteoric water. Similar processes were also documented in [26,27].

Notably, the Py2b displays oscillatory zoning of As, Co, Ni, and Au (Figure 10) and cataclastic textures (Figure $5 \mathrm{f}-\mathrm{h}, \mathrm{j}$ ). Oscillatory zoning of pyrite can be attributed to multiple hydrothermal fluid inputs or variable growth rates driven by periodic changes of fluid conditions (e.g., pressure, temperature, and $\mathrm{pH}[25,36,42,43,47])$. A previous study proposed the formation of pyrite and other sulfide minerals of the Sizhuang deposit from a single hydrothermal fluid by $\mathrm{H}_{2} \mathrm{~S}$ continuous separation into vapor phase through fluid immiscibility [57]. But pyrite precipitated from a single fluid rarely exhibits a correlation among major and trace elements. Iron of Py2b is weakly associated with As $(r=0.455)$ and $\mathrm{Au}(\mathrm{r}=0.530$; Table S2), and there are many mineralized veins and breccia occurrences in stage 2 (Figure 3). This excludes the possibility of a single hydrothermal event and alternatively suggests an open hydrothermal system. The sharp textural features formed during Py $2 b$ growth (e.g., irregular bands and overgrowth on cataclastic texture; Figure 5) and corresponding compositional transition (Figure 10) are consistent with an open fluid environment with large fluid fluxes or multiple fluid charging events. Thus, the oscillatory zoning at Sizhuang likely reflects episodic changes in the composition (As, $\mathrm{Co}, \mathrm{Ni}$, and $\mathrm{Au}$ ) of pyrite-precipitating fluid. However, the homogeneous distribution of the $\mathrm{S}$ isotope in individual pyrite crystals at Sizhuang [57] requires a similar source for multiple ingresses of fluids. However, the changes or fluctuations in fluid compositions can explain only a subset of the variations observed in pyrite geochemistry. The variation of fluid pressures (about $0.5-3.5$ kbar) estimated by fluid inclusions from auriferous quartz veins suggests the pressure fluctuations during mineralization $[58,65]$. Thus, the complex pyrite textures with respect to micro-structural deformation and subsequent pyrite overgrowth and other mineral filling or healing (Figure 5e-g; [57]) additionally reflect effects on pyrite growth by fluid pressure changes, as suggested in $[28,95,96]$.

The Py2c, as the late phase of Py2, is marked by high As-Au concentrations and other trace elements (e.g., $\mathrm{Ni}, \mathrm{Ag}, \mathrm{Sb}$, and $\mathrm{Te}$ ). Pyrite in-situ $\mathrm{S}$ isotope data show the pyrite formed in stage 2 and As-rich pyrite have similar isotopic compositions (8.1-9.6\%, mean $8.8 \%$, and $7.5-9.8 \%$, mean $9.0 \%$, respectively; [57]), suggesting a similar source for fluids precipitating Py $2 \mathrm{~b}$ and Py2c. There are two possible sources of As-rich fluids during late stage 2: (1) mobilization of As from early-formed pyrite via dissolution-reprecipitation processes, and (2) progressive inputs of external waters, similar to that proposed for Py2b. The remobilization and redistribution of metals (e.g., $\mathrm{Au}, \mathrm{As}, \mathrm{Pb}$ ) has been recognized in many orogenic gold systems as the result of progressive ore-forming evolution or reworking processes $[37,38,41,97,98]$. However, given the local sharp boundaries between Py $2 \mathrm{~b}$ and Py2c (Figure 5g), we suggest that the Py2c geochemistry was dominantly controlled by hydrothermal fluids rather than metal redistribution. This is consistent with the progressive compositional changes (e.g., progressively elevated Ni, As, Ag, Au, and Te) from Py2a to Py2c during stage 2. Such processes were likely linked to the continuous interaction between fluids and country rocks as the characteristics of the protolith had locally or totally disappeared due to quartz-sericite-pyrite alteration of stage 2 (Figure 3c,e-h).

Py3 exhibits fine-grained anhedral crystals, reflecting rapid precipitation from solutions. The occurrence of abundant syn-stage siderite suggests a carbon- and Fe-rich fluid. The mineral replacement of pyrrhotite by pyrite (Py3) during early stage 3 generated the dissolution and colloform textures (Figure 6d), which could release metals into fluids for late sulfide growth [99]. But the high $\mathrm{Cu} / \mathrm{Ni}, \mathrm{As} / \mathrm{Ni}$, and $\mathrm{Au} / \mathrm{Co}$ ratios of Py3 and the formation of marcasite required a fluid with low temperature (likely $<240{ }^{\circ} \mathrm{C}$; [92]) or low metal budgets. As discussed previously, an input of meteoric water after an intermittent episode provides a reasonable mechanism for temperature decreasing and/or dilution of ore fluids. 


\subsection{Metallogenic Implications}

Gold deposition at Sizhuang occurred in stages 1-3, with stage 2 (quartz-sericite-Py2) being the primary gold-introducing episode. Gold mineralization of stage 2 is marked by the formation of Py $2 \mathrm{~b}$ and Py2c both of which are enriched in As (Figures 7 and 8). In addition, the As-rich pyrite zones have relatively high gold concentrations (Figure 10) and most visible gold grains are hosted in the fractures of Py2 with no evidence of dissolution texture (Figure 5e,i; [58]), suggesting that gold precipitated directly from hydrothermal fluids. This study suggests the ore-forming fluid evolution in the Sizhuang gold deposit began with magmatic water dominant in stage 1 , meteoric waters impacting early stage 2 , a mixture of magmatic and external waters in middle-late stage 2 , and external waters in stage 3. The fluid evolution is in essence the result of a series of pulsed deep fluids release plus progressive ingress of external fluids. We propose that a mix of deep magmatic and shallow external waters (stage 2) generated the orogenic gold mineralization at Sizhuang.

In addition to the composition of fluids (e.g., total metal concentrations) as a prerequisite for mineralization, effective traps and precipitation mechanisms are important factors for controlling economic mineralization $[100,101]$. We noticed that abundant mineral inclusions, especially of chalcopyrite, are observed in the As-rich and Co-poor bands of Py2 (Figure 10). Chalcopyrite inclusions in pyrite could be attributed to the voids in pyrite crystal structure (e.g., $[27,29,34])$ or a rapid deposition and crystallization of $\mathrm{Cu}$ followed by progressive clusters (e.g., [48]). The first mechanism restricts the size and amounts of inclusions and is thus less possible for the Sizhuang pyrite. Previous studies have demonstrated that there are contemporaneous primary $\mathrm{H}_{2} \mathrm{O}-\mathrm{CO}_{2}$ and aqueous inclusions in auriferous quartz-sulfide veins with variable densities, implying the occurrence of phase separation during mineralization $[58,65]$. Phase separation with simultaneous decompression and fast volatile exsolution from fluids can lead to the destabilization of complexes and subsequent arsenic and metal (e.g., $\mathrm{Au}, \mathrm{Cu}$ ) separation from fluids (e.g., [25,31,86,102,103]). Due to a lower sensitivity of Co complexes to pressure changes [48], phase separation typically results in the pyrite characteristic of relatively high concentrations of $\mathrm{As}, \mathrm{Cu}$, and $\mathrm{Au}$ and low Co concentrations [48]. Moreover, the fluid phase separation accompanying vapor escaping would partly decrease the temperature of fluid system, which is also favorable in metal deposition [25,31,48]. Furthermore, the quiet period (aseismic) after fluid pressure releasing during phase separation is conducive to metal self-organization and mineral crystal growth (e.g., [96]). Collectively, it is highly likely that rapid phase separation accompanying pressure releases occurred during Py $2 \mathrm{~b}$ crystallization that formed As-Cu-rich and Co-poor bands. Such a scenario involving rapid pressure drops and subsequent growth is perhaps applied for the free electrum growth in fractures (e.g., [18]).

The alteration-mineralization zone of the Sizhuang deposit as well as most Jiaodongtype orogenic deposits, especially veinlet-disseminated types, was developed as a veinbreccia system in regional detachment fault zones $[5,22,23,53,56]$. The strong brecciation in the ductile-brittle system of the Jiaojia fault at Sizhuang (Figure 3c,e) would have been a highly efficient mechanism for rapid pressure release (phase separation), resulting in the observed characteristic of pyrite, such as zonation and overgrowth on cataclastic texture and $\mathrm{Cu}$-enrichment by abundant chalcopyrite inclusions in $\mathrm{Au}$ - and As-rich and Co-poor bands. Moreover, the dilation portions of fault zones at Sizhuang were also interpreted as preferential locations for fluid flowing and pooling during the dextral and normal movement of the Jiaojia fault [55]. Such a coupled control on fluid pooling and metal deposition from seismic movement along fault zones is consistent with the fault-valve regime of many orogenic gold systems (e.g., [39,41,104-106]).

\section{Conclusions}

(1) Three types of hydrothermal pyrite are recognized at the Sizhuang gold deposit: (I) stage 1 disseminated pyrite (Py1) hosted in K-feldspar-albite-rutile and quartz-sericite altered rocks, (II) stage 2 pyrite in quartz-pyrite veins or quartz-sericite-pyrite altered rocks or breccias (Py2) occurring as irregular cores (Py2a), middle- to coarse-grained and zoned 
and cataclastic crystals (Py2b) and overgrowth Py2c, and finally, (III) stage 3 anhedral fine-grained pyrite (Py3) in siderite-polymetallic sulfide veins.

(2) Gold occurs as the solid solution $\left(\mathrm{Au}^{+}\right)$in Py1, Py2b, and Py2c associated with As incorporation, or electrum inclusions in Py $2 b, P y 2 c$, and Py 3 that are formed together with galena.

(3) Py1 with high Co and Ni contents was formed due to the interaction between magmatic waters and wall rocks. Py2a with very low trace element contents (e.g., $\mathrm{Co}, \mathrm{Ni}$, As, and $\mathrm{Te}$ ) was associated with decreased temperature or fluid dilution related to the influx of meteoric waters during early stage 2 , whereas Py $2 \mathrm{~b}$ and Py2c were precipitated in association with the mixture of new pulse of magmatic waters and external waters in middle-late stage 2. The composition of pyrite from stage 3 is affected by the input of meteoric waters during the waning stages of the hydrothermal system.

(4) Gold mineralization in the Sizhuang deposit was controlled both by fluid compositions, physico-chemical properties, and shallow-crustal structural deformation. Gold deposition in the Sizhuang and other Jiaodong-type orogenic gold systems was closely associated with the pressure rapid decreases or fluctuations in a fault-valve regime.

Supplementary Materials: The following are available online at https:/ /www.mdpi.com/2075-163 X/11/4/344/s1, Table S1: Chemical compositions of pyrite from the Sizhuang gold deposit measured by EPMA (in wt \%) and LA-ICP-MS (in ppm). Table S2: The inter-element correlation coefficients of the Sizhuang pyrite geochemistry determined by LA-ICP-MS.

Author Contributions: Conceptualization, Z.L. and X.M.; experiments, Z.L., H.D. and J.C.; field investigation, Z.L.; writing—original draft preparation, Z.L.; writing—review and editing, X.M., A.J., R.C.B. and K.X. All authors have read and agreed to the published version of the manuscript.

Funding: This research was funded by National Key R\&D Program of China (grant number 2017YFC0601503) and National Natural Science Foundation of China (grant numbers 41772349, 41972309, 42030809, and 42072325).

Data Availability Statement: Not applicable.

Acknowledgments: This paper has been significantly improved by critical reviews by three anonymous reviewers. Pete Hollings and Daniel Müller are greatly appreciated for their constructive comments on the early draft. We thank Fenglin Zhao of the Shandong Gold Group Co. Ltd. for permitting access to the Sizhuang gold mine.

Conflicts of Interest: The authors declare no conflict of interest.

\section{References}

1. Deng, J.; Yang, L.-Q.; Groves, D.I.; Zhang, L.; Qiu, K.-F.; Wang, Q.-F. An integrated mineral system model for the gold deposits of the giant Jiaodong province, eastern China. Earth-Sci. Rev. 2020, 208, 103274. [CrossRef]

2. Fan, H.-R.; Zhai, M.; Yang, K.-F.; Hu, F.-F. Late Mesozoic Gold Mineralization in the North China Craton. In Main Tectonic Events and Metallogeny of the North China Craton; Springer: Singapore, 2016; pp. 511-525.

3. Goldfarb, R.J.; Santosh, M. The dilemma of the Jiaodong gold deposits: Are they unique? Geosci. Front. 2014, 5, 139-153. [CrossRef]

4. Groves, D.I.; Santosh, M. The giant Jiaodong gold province: The key to a unified model for orogenic gold deposits? Geosci. Front. 2016, 7, 409-417. [CrossRef]

5. Song, M.-C.; Li, S.-Z.; Santosh, M.; Zhao, S.; Yu, S.; Yi, P.-H.; Cui, S.-X.; Lv, G.-X.; Xu, J.-X.; Song, Y.-X.; et al. Types, characteristics and metallogenesis of gold deposits in the Jiaodong Peninsula, Eastern North China Craton. Ore Geol. Rev. 2015, 65, 612-625. [CrossRef]

6. Qiu, Y.; Groves, D.I.; McNaughton, N.J.; Wang, L.-G.; Zhou, T. Nature, age, and tectonic setting of granitoid-hosted, orogenic gold deposits of the Jiaodong Peninsula, eastern North China craton, China. Miner. Deposita 2002, 37, 283-305. [CrossRef]

7. Li, L.; Santosh, M.; Li, S.-R. The 'Jiaodong type' gold deposits: Characteristics, origin and prospecting. Ore Geol. Rev. 2015, 65, 589-611. [CrossRef]

8. Guo, L.-N.; Goldfarb, R.J.; Wang, Z.-L.; Li, R.-H.; Chen, B.-H.; Li, J.-L. A comparison of Jiaojia- and Linglong-type gold deposit ore-forming fluids: Do they differ? Ore Geol. Rev. 2017, 88, 511-533. [CrossRef]

9. Fan, H.R.; Zhai, M.G.; Xie, Y.H.; Yang, J.H. Ore-forming fluids associated with granite-hosted gold mineralization at the Sanshandao deposit, Jiaodong gold province, China. Miner. Deposita 2003, 38, 739-750. [CrossRef] 
10. Cai, Y.-C.; Fan, H.-R.; Santosh, M.; Hu, F.-F.; Yang, K.-F.; Li, X.-H. Decratonic gold mineralization: Evidence from the Shangzhuang gold deposit, eastern North China Craton. Gondwana Res. 2018, 54, 1-22. [CrossRef]

11. Li, J.; Vasconcelos, P.; Zhou, M.; Zhao, X.; Ma, C. Geochronology of the Pengjiakuang and Rushan Gold Deposits, Eastern Jiaodong Gold Province, Northeastern China: Implications for Regional Mineralization and Geodynamic Setting. Econ. Geol. 2006, 101, 1023-1038. [CrossRef]

12. Zhang, L.; Weinberg, R.F.; Yang, L.-Q.; Groves, D.I.; Sai, S.-X.; Matchan, E.; Phillips, D.; Kohn, B.P.; Miggins, D.P.; Liu, Y.; et al. Mesozoic Orogenic Gold Mineralization in the Jiaodong Peninsula, China: A Focused Event at $120 \pm 2$ Ma During Cooling of Pregold Granite Intrusions. Econ. Geol. 2020, 115, 415-441. [CrossRef]

13. Groves, D.; Goldfarb, R.; Gebre-Mariam, M.; Hagemann, S.; Robert, F. Orogenic gold deposits: A proposed classification in the context of their crustal distribution and relationship to other gold deposit types. Ore Geol. Rev. 1998, 13, 7-27. [CrossRef]

14. Groves, D.I.; Santosh, M.; Deng, J.; Wang, Q.; Yang, L.; Zhang, L. A holistic model for the origin of orogenic gold deposits and its implications for exploration. Miner. Deposita 2020, 55, 275-292. [CrossRef]

15. Goldfarb, R.J.; Baker, T.; Dubé, B.; Groves, D.I.; Hart, C.J.; Gosselin, P. Distribution, Character, and Genesis of Gold Deposits in Metamorphic Terran. In One Hundredth Anniversary Volume; Society of Economic Geologists: Littleton, CO, USA, 2005; pp. 407-450.

16. Santosh, M.; Pirajno, F. The Jiaodong-type gold deposits: Introduction. Ore Geol. Rev. 2015, 65, 565-567. [CrossRef]

17. Deng, J.; Liu, X.; Wang, Q.; Pan, R. Origin of the Jiaodong-type Xinli gold deposit, Jiaodong Peninsula, China: Constraints from fluid inclusion and C-D-O-S-Sr isotope compositions. Ore Geol. Rev. 2015, 65, 674-686. [CrossRef]

18. Yang, L.-Q.; Deng, J.; Wang, Z.-L.; Guo, L.-N.; Li, R.-H.; Groves, D.I.; Danyushevsky, L.V.; Zhang, C.; Zheng, X.-L.; Zhao, H. Relationships Between Gold and Pyrite at the Xincheng Gold Deposit, Jiaodong Peninsula, China: Implications for Gold Source and Deposition in a Brittle Epizonal Environment. Econ. Geol. 2016, 111, 105-126. [CrossRef]

19. Ma, W.-D.; Fan, H.-R.; Liu, X.; Pirajno, F.; Hu, F.-F.; Yang, K.-F.; Yang, Y.-H.; Xu, W.-G.; Jiang, P. Geochronological framework of the Xiadian gold deposit in the Jiaodong province, China: Implications for the timing of gold mineralization. Ore Geol. Rev. 2017, 86, 196-211. [CrossRef]

20. Wen, B.-J.; Fan, H.-R.; Hu, F.-F.; Liu, X.; Yang, K.-F.; Sun, Z.-F.; Sun, Z.-F. Fluid evolution and ore genesis of the giant Sanshandao gold deposit, Jiaodong gold province, China: Constrains from geology, fluid inclusions and H-O-S-He-Ar isotopic compositions. J. Geochem. Explor. 2016, 171, 96-112. [CrossRef]

21. Tian, J.; Li, J.; Zhang, P.; Li, X.; Liu, W.; Tang, W.; Fu, C.; Dang, Z.; He, J. Formation of the Majiayao gold deposit, Jiaodong Peninsula, eastern China: Constraints from fluid inclusions, H-O-S-Pb isotopes, and pyrite Rb-Sr age. Geol. J. 2019, 55, 5885-5902. [CrossRef]

22. Deng, J.; Yang, L.-Q.; Li, R.-H.; Groves, D.I.; Santosh, M.; Wang, Z.-L.; Sai, S.-X.; Wang, S.-R. Regional structural control on the distribution of world-class gold deposits: An overview from the Giant Jiaodong Gold Province, China. Geol. J. 2019, 54, 378-391. [CrossRef]

23. Mao, X.; Ren, J.; Liu, Z.; Chen, J.; Tang, L.; Deng, H.; Bayless, R.C.; Yang, B.; Wang, M.; Liu, C. Three-dimensional prospectivity modeling of the Jiaojia-type gold deposit, Jiaodong Peninsula, Eastern China: A case study of the Dayingezhuang deposit. J. Geochem. Explor. 2019, 203, 27-44. [CrossRef]

24. George, L.L.; Biagioni, C.; D'Orazio, M.; Cook, N.J. Textural and trace element evolution of pyrite during greenschist facies metamorphic recrystallization in the southern Apuan Alps (Tuscany, Italy): Influence on the formation of Tl-rich sulfosalt melt. Ore Geol. Rev. 2018, 102, 59-105. [CrossRef]

25. Li, X.-H.; Fan, H.-R.; Yang, K.-F.; Hollings, P.; Liu, X.; Hu, F.-F.; Cai, Y.-C. Pyrite textures and compositions from the Zhuangzi Au deposit, southeastern North China Craton: Implication for ore-forming processes. Contrib. Miner. Pet. 2018, 173, 73. [CrossRef]

26. Liu, Z.; Mao, X.; Deng, H.; Li, B.; Zhang, S.; Lai, J.; Bayless, R.C.; Pan, M.; Li, L.; Shang, Q. Hydrothermal processes at the Axi epithermal Au deposit, western Tianshan: Insights from geochemical effects of alteration, mineralization and trace elements in pyrite. Ore Geol. Rev. 2018, 102, 368-385. [CrossRef]

27. Tardani, D.; Reich, M.; Deditius, A.P.; Chryssoulis, S.; Sánchez-Alfaro, P.; Wrage, J.; Roberts, M.P. Copper-arsenic decoupling in an active geothermal system: A link between pyrite and fluid composition. Geochim. Cosmochim. Acta 2017, 204, 179-204. [CrossRef]

28. Wu, Y.-F.; Li, J.-W.; Evans, K.; Koenig, A.E.; Li, Z.-K.; O’Brien, H.; Lahaye, Y.; Rempel, K.; Hu, S.-Y.; Zhang, Z.-P.; et al. Ore-Forming Processes of the Daqiao Epizonal Orogenic Gold Deposit, West Qinling Orogen, China: Constraints from Textures, Trace Elements, and Sulfur Isotopes of Pyrite and Marcasite, and Raman Spectroscopy of Carbonaceous Material. Econ. Geol. 2018, 113, 1093-1132. [CrossRef]

29. Reich, M.; Deditius, A.; Chryssoulis, S.; Li, J.-W.; Ma, C.-Q.; Parada, M.A.; Barra, F.; Mittermayr, F. Pyrite as a record of hydrothermal fluid evolution in a porphyry copper system: A SIMS/EMPA trace element study. Geochim. Cosmochim. Acta 2013, 104, 42-62. [CrossRef]

30. Reich, M.; Simon, A.C.; Deditius, A.; Barra, F.; Chryssoulis, S.; Lagas, G.; Tardani, D.; Knipping, J.; Bilenker, L.; Sánchez-Alfaro, P.; et al. Trace element signature of pyrite from the Los Colorados iron oxide-apatite (IOA) deposit, Chile: A missing link between Andean IOA and iron oxide copper-gold systems? Econ. Geol. 2016, 111, 743-761. [CrossRef]

31. Sykora, S.; Cooke, D.R.; Meffre, S.; Stephanov, A.S.; Gardner, K.; Scott, R.; Selley, D.; Harris, A.C. Evolution of Pyrite Trace Element Compositions from Porphyry-Style and Epithermal Conditions at the Lihir Gold Deposit: Implications for Ore Genesis and Mineral Processing. Econ. Geol. 2018, 113, 193-208. [CrossRef] 
32. Cook, N.J.; Ciobanu, C.L.; Meria, D.; Silcock, D.; Wade, B. Arsenopyrite-Pyrite Association in an Orogenic Gold Ore: Tracing Mineralization History from Textures and Trace Elements. Econ. Geol. 2013, 108, 1273-1283. [CrossRef]

33. Deditius, A.P.; Reich, M.; Kesler, S.E.; Utsunomiya, S.; Chryssoulis, S.L.; Walshe, J.; Ewing, R.C. The coupled geochemistry of Au and As in pyrite from hydrothermal ore deposits. Geochim. Cosmochim. Acta 2014, 140, 644-670. [CrossRef]

34. Deditius, A.P.; Utsunomiya, S.; Reich, M.; Kesler, S.E.; Ewing, R.C.; Hough, R.; Walshe, J. Trace metal nanoparticles in pyrite. Ore Geol. Rev. 2011, 42, 32-46. [CrossRef]

35. Keith, M.; Smith, D.J.; Doyle, K.; Holwell, D.A.; Jenkin, G.R.; Barry, T.L.; Becker, J.; Rampe, J. Pyrite chemistry: A new window into $\mathrm{Au}$-Te ore-forming processes in alkaline epithermal districts, Cripple Creek, Colorado. Geochim. Cosmochim. Acta 2020, 274, 172-191. [CrossRef]

36. Wu, Y.-F.; Fougerouse, D.; Evans, K.; Reddy, S.M.; Saxey, D.W.; Guagliardo, P.; Li, J.-W. Gold, arsenic, and copper zoning in pyrite: A record of fluid chemistry and growth kinetics. Geology 2019, 47, 641-644. [CrossRef]

37. Dubosq, R.; Lawley, C.; Rogowitz, A.; Schneider, D.; Jackson, S. Pyrite deformation and connections to gold mobility: Insight from micro-structural analysis and trace element mapping. Lithos 2018, 310-311, 86-104. [CrossRef]

38. Hastie, E.C.; Kontak, D.J.; Lafrance, B. Gold Remobilization: Insights from Gold Deposits in the Archean Swayze Greenstone Belt, Abitibi Subprovince, Canada. Econ. Geol. 2020, 115, 241-277. [CrossRef]

39. Peterson, E.C.; Mavrogenes, J.A. Linking high-grade gold mineralization to earthquake-induced fault-valve processes in the Porgera gold deposit, Papua New Guinea. Geology 2014, 42, 383-386. [CrossRef]

40. Rottier, B.; Kouzmanov, K.; Wälle, M.; Bendezú, R.; Fontboté, L. Sulfide Replacement Processes Revealed by Textural and LA-ICP-MS Trace Element Analyses: Example from the Early Mineralization Stages at Cerro de Pasco, Peru. Econ. Geol. 2016, 111, 1347-1367. [CrossRef]

41. Wu, Y.-F.; Evans, K.; Li, J.-W.; Fougerouse, D.; Large, R.R.; Guagliardo, P. Metal remobilization and ore-fluid perturbation during episodic replacement of auriferous pyrite from an epizonal orogenic gold deposit. Geochim. Cosmochim. Acta 2019, 245, 98-117. [CrossRef]

42. Baidya, A.S.; Sen, A.; Pal, D.C.; Upadhyay, D. Ore-forming processes in the Khetri Copper Belt, western India: Constraints from trace element chemistry of pyrite and CO isotope composition of carbonates. Miner. Deposita 2020, 1-18. [CrossRef]

43. Barker, S.L.L.; Hickey, K.A.; Cline, J.S.; Dipple, G.M.; Kilburn, M.R.; Vaughan, J.R.; Longo, A.A. uncloaking invisible gold: Use of nanosims to evaluate gold, trace elements, and sulfur isotopes in pyrite from Carlin-type gold deposits. Econ. Geol. 2009, 104, 897-904. [CrossRef]

44. Chinnasamy, S.S.; Hazarika, P.; Pal, D.; Sen, R.; Govindaraj, G. Pyrite textures and trace element compositions from the granodiorite-hosted gold deposit at Jonnagiri, eastern Dharwar craton, India: Implications for gold mineralization processes. Econ. Geol. 2020. [CrossRef]

45. Cook, N.J.; Ciobanu, C.L.; Mao, J. Textural control on gold distribution in As-free pyrite from the Dongping, Huangtuliang and Hougou gold deposits, North China Craton (Hebei Province, China). Chem. Geol. 2009, 264, 101-121. [CrossRef]

46. Tauson, V.L. Gold solubility in the common gold-bearing minerals: Experimental evaluation and application to pyrite. Eur. J. Miner. 1999, 11, 937-948. [CrossRef]

47. Velasquez, G.; Beziat, D.; Salvi, S.; Siebenaller, L.; Borisova, A.Y.; Pokrovski, G.S.; De Parseval, P. Formation and Deformation of Pyrite and Implications for Gold Mineralization in the El Callao District, Venezuela. Econ. Geol. 2013, 109, 457-486. [CrossRef]

48. Román, N.; Reich, M.; Leisen, M.; Morata, D.; Barra, F.; Deditius, A.P. Geochemical and micro-textural fingerprints of boiling in pyrite. Geochim. Cosmochim. Acta 2019, 246, 60-85. [CrossRef]

49. Large, R.R.; Bull, S.W.; Maslennikov, V.V. A Carbonaceous Sedimentary Source-Rock Model for Carlin-Type and Orogenic Gold Deposits. Econ. Geol. 2011, 106, 331-358. [CrossRef]

50. Feng, K.; Fan, H.-R.; Hu, F.-F.; Yang, K.-F.; Liu, X.; Shangguan, Y.-N.; Cai, Y.-C.; Jiang, P. Involvement of anomalously As-Au-rich fluids in the mineralization of the Heilan'gou gold deposit, Jiaodong, China: Evidence from trace element mapping and in-situ sulfur isotope composition. J. Asian Earth Sci. 2018, 160, 304-321. [CrossRef]

51. Mills, S.E.; Tomkins, A.G.; Weinberg, R.F.; Fan, H.-R. Implications of pyrite geochemistry for gold mineralisation and remobilisation in the Jiaodong gold district, northeast China. Ore Geol. Rev. 2015, 71, 150-168. [CrossRef]

52. Li, R.; Wang, X.; Yang, L.; Zhang, B.; Liu, Q.; Liu, D. The characteristic of microstructural deformation of gold bearing pyrite in Jiaodong: The links between nanoscale gold enrichment and crystal distortion. Ore Geol. Rev. 2020, 122, 103495. [CrossRef]

53. Wang, S.-R.; Yang, L.-Q.; Wang, J.-G.; Wang, E.-J.; Xu, Y.-L. Geostatistical Determination of Ore Shoot Plunge and Structural Control of the Sizhuang World-Class Epizonal Orogenic Gold Deposit, Jiaodong Peninsula, China. Minerals 2019, 9, 214. [CrossRef]

54. Deng, J.; Wang, C.; Bagas, L.; Carranza, E.J.M.; Lu, Y. Cretaceous-Cenozoic tectonic history of the Jiaojia Fault and gold mineralization in the Jiaodong Peninsula, China: Constraints from zircon $\mathrm{U}-\mathrm{Pb}$, illite $\mathrm{K}-\mathrm{Ar}$, and apatite fission track thermochronometry. Miner. Deposita 2015, 50, 987-1006. [CrossRef]

55. Hao, W.; LiQiang, Y.; Sirui, W.; Liang, Z.; Yuji, W.; Guangyao, L. The process of rubefication and its relationship with gold mineralization of Sizhuang gold deposit, northwestern Jiaodong Peninsula, eastern China. Acta Pet. Sin. 2020, 36, 1515-1528. [CrossRef]

56. Cui, S.; Yuan, W. Ore-forming regularity of the second enrichment zone of the Sizhuang gold deposit in Laizhou, Shandong Province. Geol. Surv. Res. 2008, 31, 186-191. 
57. Hu, H.-L.; Fan, H.-R.; Liu, X.; Cai, Y.-C.; Yang, K.-F.; Ma, W.-D. Two-stage gold deposition in response to $\mathrm{H}_{2} \mathrm{~S}$ loss from a single fluid in the Sizhuang deposit (Jiaodong, China). Ore Geol. Rev. 2020, 120, 103450. [CrossRef]

58. Feng, J. Characteristics and Evolution of Ore-Forming Fluid in the Sizhuang Gold Deposit; Jiaodong Peninsula; China University of Geosciences: Beijing, China, 2016.

59. Reich, M.; Kesler, S.E.; Utsunomiya, S.; Palenik, C.S.; Chryssoulis, S.L.; Ewing, R.C. Solubility of gold in arsenian pyrite. Geochim. Cosmochim. Acta 2005, 69, 2781-2796. [CrossRef]

60. Zoheir, B.; Deshesh, F.; Broman, C.; Pitcairn, I.; El-Metwally, A.; Mashaal, S. Granitoid-associated gold mineralization in Egypt: A case study from the Atalla mine. Miner. Deposita 2017, 53, 701-720. [CrossRef]

61. Tauson, V.; Lipko, S. Solubility of Gold in Common Gold-Concentrating Minerals. Russ. Geol. Geophys. 2020, 61, 1331-1344. [CrossRef]

62. Tauson, V.; Lipko, S.; Kravtsova, R.; Smagunov, N.; Belozerova, O.; Voronova, I. Distribution of "Invisible" Noble Metals between Pyrite and Arsenopyrite Exemplified by Minerals Coexisting in Orogenic Au Deposits of North-Eastern Russia. Minerals 2019, 9, 660. [CrossRef]

63. Tauson, V.; Kravtsova, R.; Smagunov, N.; Spiridonov, A.; Grebenshchikova, V.; Budyak, A. Structurally and superficially bound gold in pyrite from deposits of different genetic types. Russ. Geol. Geophys. 2014, 55, 273-289. [CrossRef]

64. Shannon, R.D. Revised effective ionic radii and systematic studies of interatomic distances in halides and chalcogenides. Acta Crystallogr. 1976, 32, 751-767. [CrossRef]

65. Wei, Q.; Fan, H.; Lan, T.; Liu, X.; Jiang, X.; Wen, B. Genesis of Sizhuang gold deposit, Jiaodong Peninsula: Evidences from fluid inclusion and quartz solubility modeling. Acta Petrol. Sinica 2015, 31, 1049-1062.

66. Williams-Jones, A.E.; Bowell, R.J.; Migdisov, A.A. Gold in Solution. Elements 2009, 5, 281-287. [CrossRef]

67. George, L.; Cook, N.J.; Ciobanu, C.L.; Wade, B.P. Trace and minor elements in galena: A reconnaissance LA-ICP-MS study. Am. Miner. 2015, 100, 548-569. [CrossRef]

68. Renock, D.; Becker, U. A first principles study of coupled substitution in galena. Ore Geol. Rev. 2011, 42, 71-83. [CrossRef]

69. Palero-Fernández, F.; Martín-Izard, A. Trace element contents in galena and sphalerite from ore deposits of the Alcudia Valley mineral field (Eastern Sierra Morena, Spain). J. Geochem. Explor. 2005, 86, 1-25. [CrossRef]

70. Tauson, V.; Smagunov, N.; Akimov, V.; Datkov, V. Mechanisms and species of gold incorporation into crystals of cadmium, lead, and iron sulfides. Russ. Geol. Geophys. 2008, 49, 594-601. [CrossRef]

71. Lipko, S.; Tauson, V.; Bychinskii, V. Gold Partitioning in a Model Multiphase Mineral-Hydrothermal Fluid System: Distribution Coefficients, Speciation and Segregation. Minerals 2020, 10, 890. [CrossRef]

72. Yuan, Z.-Z.; Li, Z.-K.; Zhao, X.-F.; Sun, H.-S.; Qiu, H.-N.; Li, J.-W. New constraints on the genesis of the giant Dayingezhuang gold (silver) deposit in the Jiaodong district, North China Craton. Ore Geol. Rev. 2019, 112, 103038. [CrossRef]

73. Liu, Z.-K.; Mao, X.-C.; Wang, F.-Y.; Tang, L.; Chen, G.-H.; Chen, J.; Deng, H. Deciphering the anomalous Ag enrichment in the Dayingezhuang $\mathrm{Au}(-\mathrm{Ag})$ deposit, Jiaodong Peninsula, Eastern China using texture, geochemistry and in-situ Pb iso-tope of galena. Trans. Nonferrous Met. Soc. China. under review.

74. Liu, Z.; Hollings, P.; Mao, X.; Lawley, C.J.; Yang, B.; Tang, L. Metal remobilization from country rocks into the Jiaodong-type orogenic gold systems, Eastern China: New constraints from scheelite and galena isotope results at the Xiadian and Majiayao gold deposits. Ore Geol. Rev. 2021, 104126. [CrossRef]

75. Tauson, V.; Babkin, D.; Akimov, V.; Lipko, S.; Smagunov, N.; Parkhomenko, I. Trace elements as indicators of the physicochemical conditions of mineral formation in hydrothermal sulfide systems. Russ. Geol. Geophys. 2013, 54, 526-543. [CrossRef]

76. Tauson, V.L.; Lipko, S.V.; Smagunov, N.V.; Kravtsova, R.G. Trace Element Partitioning Dualism under Mineral-Fluid Interaction: Origin and Geochemical Significance. Minerals 2018, 8, 282. [CrossRef]

77. Tauson, V.; Lipko, S.; Smagunov, N.; Kravtsova, R.; Arsent'Ev, K. Distribution and segregation of trace elements during the growth of ore mineral crystals in hydrothermal systems: Geochemical and mineralogical implications. Russ. Geol. Geophys. 2018, 59, 1718-1732. [CrossRef]

78. Mavrogonatos, C.; Voudouris, P.; Zaccarini, F.; Klemme, S.; Berndt, J.; Tarantola, A.; Melfos, V.; Spry, P.G. Multi-Stage Introduction of Precious and Critical Metals in Pyrite: A Case Study from the Konos Hill and Pagoni Rachi Porphyry/Epithermal Prospects, NE Greece. Minerals 2020, 10, 784. [CrossRef]

79. Liu, Z.; Mao, X.; Ackerman, L.; Li, B.; Dick, J.M.; Yu, M.; Peng, J.; Shahzad, S.M. Two-stage gold mineralization of the Axi epithermal Au deposit, Western Tianshan, NW China: Evidence from Re-Os dating, S isotope, and trace elements of pyrite. Miner. Deposita 2019, 55, 863-880. [CrossRef]

80. Jansson, N.F.; Liu, W. Controls on cobalt and nickel distribution in hydrothermal sulphide deposits in Bergslagen, Sweden constraints from solubility modelling. GFF 2020, 142, 87-95. [CrossRef]

81. Maslennikov, V.V.; Cherkashov, G.; Artemyev, D.A.; Firstova, A.; Large, R.R.; Tseluyko, A.; Kotlyarov, V. Pyrite Varieties at Pobeda Hydrothermal Fields, Mid-Atlantic Ridge $17^{\circ} 07^{\prime}-17^{\circ} 08^{\prime}$ N: LA-ICP-MS Data Deciphering. Minerals 2020, 10, 622. [CrossRef]

82. Huston, D.L.; Sie, S.H.; Suter, G.F.; Cooke, D.R.; Both, R.A. Trace elements in sulfide minerals from eastern Australian volcanichosted massive sulfide deposits; Part I, Proton microprobe analyses of pyrite, chalcopyrite, and sphalerite, and Part II, Selenium levels in pyrite; comparison with delta ${ }^{34} \mathrm{~S}$ values and implications for the source of sulfur in volcanogenic hydrothermal systems. Econ. Geol. 1995, 90, 1167-1196. [CrossRef] 
83. Nash, J.T. Geology and Geochemistry of Synsedimentary Cobaltiferous-Pyrite Deposits, Iron Creek, Lemhi County, Idaho; US Gov: Washington, DC, USA, 1989; pp. 1-33. [CrossRef]

84. Witt, W.K.; Hagemann, S.G.; Roberts, M.; Davies, A. Cobalt enrichment at the Juomasuo and Hangaslampi polymetallic deposits, Kuusamo Schist Belt, Finland: A role for an orogenic gold fluid? Miner. Deposita 2020, 55, 381-388. [CrossRef]

85. Xiangdong, L.; Jun, D.; Liang, Z.; Shaoyi, L.; Mingling, Z.; Yuzhou, S.; Xiaolei, X.; ChenQin, L. Hydrothermal alteration of the Sizhuang gold deposit, northwestern Jiaodong Peninsula, eastern China. Acta Pet. Sin. 2019, 35, 1551-1565. [CrossRef]

86. Kouzmanov, K.; Pokrovski, G.S.; Hedenquist, J.; Harris, M.; Camus, F. Hydrothermal controls on metal distribution in porphyry $\mathrm{Cu}(-\mathrm{Mo}-\mathrm{Au})$ systems. Soc. Econ. Geol. Spec. Publ. 2012, 16, 573-618.

87. Pokrovski, G.S.; Zakirov, I.V.; Roux, J.; Testemale, D.; Hazemann, J.-L.; Bychkov, A.Y.; Golikova, G.V. Experimental study of arsenic speciation in vapor phase to $500{ }^{\circ} \mathrm{C}$ : Implications for as transport and fractionation in low-density crustal fluids and volcanic gases. Geochim. et Cosmochim. Acta 2002, 66, 3453-3480. [CrossRef]

88. Alford, L.; Gysi, A.P.; Hurtig, N.C.; Monecke, T.; Pfaff, K. Porphyry-related polymetallic Au-Ag vein deposit in the Central City district, Colorado: Mineral paragenesis and pyrite trace element chemistry. Ore Geol. Rev. 2020, 119, 103295. [CrossRef]

89. Sillitoe, R.H. Porphyry Copper Systems. Econ. Geol. 2010, 105, 3-41. [CrossRef]

90. Zhang, P.; Huang, X.-W.; Cui, B.; Wang, B.-C.; Yin, Y.-F.; Wang, J.-R. Re-Os isotopic and trace element compositions of pyrite and origin of the Cretaceous Jinchang porphyry Cu-Au deposit, Heilongjiang Province, NE China. J. Asian Earth Sci. 2016, 129, 67-80. [CrossRef]

91. Mansur, E.T.; Barnes, S.-J.; Duran, C.J. An overview of chalcophile element contents of pyrrhotite, pentlandite, chalcopyrite, and pyrite from magmatic Ni-Cu-PGE sulfide deposits. Miner. Deposita 2021, 56, 179-204. [CrossRef]

92. Franchini, M.; McFarlane, C.; Maydagán, L.; Reich, M.; Lentz, D.R.; Meinert, L.; Bouhier, V. Trace metals in pyrite and marcasite from the Agua Rica porphyry-high sulfidation epithermal deposit, Catamarca, Argentina: Textural features and metal zoning at the porphyry to epithermal transition. Ore Geol. Rev. 2015, 66, 366-387. [CrossRef]

93. Su, Z.-K.; Zhao, X.-F.; Li, X.-C.; Zhou, M.-F. Using elemental and boron isotopic compositions of tourmaline to trace fluid evolutions of IOCG systems: The worldclass Dahongshan Fe-Cu deposit in SW China. Chem. Geol. 2016, 441, 265-279. [CrossRef]

94. Wang, R.; Liu, Z.; Hollings, P.; Zhou, X.; Guo, Y.; Li, B.; Yu, M.; Yang, B.; Mao, X.; Lai, J. Fluid evolution of the Humedo porphyry-related gold deposit, southern Ecuador: Evidence from the boron isotope and chemical variations of tourmaline. Ore Geol. Rev. 2021, 128, 103894. [CrossRef]

95. Yang, L.-Q.; Deng, J.; Goldfarb, R.J.; Zhang, J.; Gao, B.-F.; Wang, Z.-L. ${ }^{40} \mathrm{Ar} /{ }^{39} \mathrm{Ar}$ geochronological constraints on the formation of the Dayingezhuang gold deposit: New implications for timing and duration of hydrothermal activity in the Jiaodong gold province, China. Gondwana Res. 2014, 25, 1469-1483. [CrossRef]

96. Voisey, C.R.; Willis, D.; Tomkins, A.G.; Wilson, C.J.; Micklethwaite, S.; Salvemini, F.; Bougoure, J.; Rickard, W.D. Aseismic Refinement of Orogenic Gold Systems. Econ. Geol. 2020, 115, 33-50. [CrossRef]

97. Lawley, C.J.; Creaser, R.A.; Jackson, S.E.; Yang, Z.; Davis, B.J.; Pehrsson, S.J.; Dubé, B.; Mercier-Langevin, P.; Vaillancourt, D. Unraveling the Western Churchill Province Paleoproterozoic Gold Metallotect: Constraints from Re-Os Arsenopyrite and U-Pb Xenotime Geochronology and LA-ICP-MS Arsenopyrite Trace Element Chemistry at the BIF-Hosted Meliadine Gold District, Nunavut, Canada. Econ. Geol. 2015, 110, 1425-1454. [CrossRef]

98. Lawley, C.J.; Jackson, S.; Yang, Z.; Davis, W.; Eglington, B. Tracing the transition of gold from source to sponge to sink. Econ. Geol. 2017, 112, 169-183. [CrossRef]

99. Pitcairn, I.K.; Teagle, D.A.H.; Craw, D.; Olivo, G.R.; Kerrich, R.; Brewer, T.S. Sources of metals and fluids in orogenic gold deposits: Insights from the Otago and Alpine Schists, New Zealand. Econ. Geol. 2006, 101, 1525-1546. [CrossRef]

100. Hagemann, S.; Lisitsin, V.; Huston, D. Mineral system analysis: Quo vadis. Ore Geol. Rev. 2016, 76, 504-522. [CrossRef]

101. Wyman, D.A.; Cassidy, K.F.; Hollings, P. Orogenic gold and the mineral systems approach: Resolving fact, fiction and fantasy. Ore Geol. Rev. 2016, 78, 322-335. [CrossRef]

102. Zoheir, B.A.; Akawy, A. Genesis of the Abu Marawat gold deposit, central Eastern Desert of Egypt. J. Afr. Earth Sci. 2010, 57, 306-320. [CrossRef]

103. Sanchez-Alfaro, P.; Reich, M.; Driesner, T.; Cembrano, J.; Arancibia, G.; Pérez-Flores, P.; Heinrich, C.A.; Rowland, J.; Tardani, D.; Lange, D.; et al. The optimal windows for seismically-enhanced gold precipitation in the epithermal environment. Ore Geol. Rev. 2016, 79, 463-473. [CrossRef]

104. Hronsky, J.M.A. Deposit-scale structural controls on orogenic gold deposits: An integrated, physical process-based hypothesis and practical targeting implications. Miner. Deposita 2019, 55, 197-216. [CrossRef]

105. Sibson, R.H.; Robert, F.; Poulsen, K.H. High-angle reverse faults, fluid-pressure cycling, and mesothermal gold-quartz deposits. Geology 1988, 16, 551-555. [CrossRef]

106. Cox, S.F. Faulting processes at high fluid pressures: An example of fault valve behavior from the Wattle Gully Fault, Victoria, Australia. J. Geophys. Res. Space Phys. 1995, 100, 12841-12859. [CrossRef] 